Historic, Archive Document

Do not assume content reflects current scientific knowledge, policies, or practices. 



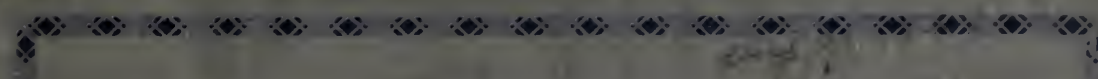

3

\section{THIRD ANNUAL}

CATALOGUE

1928

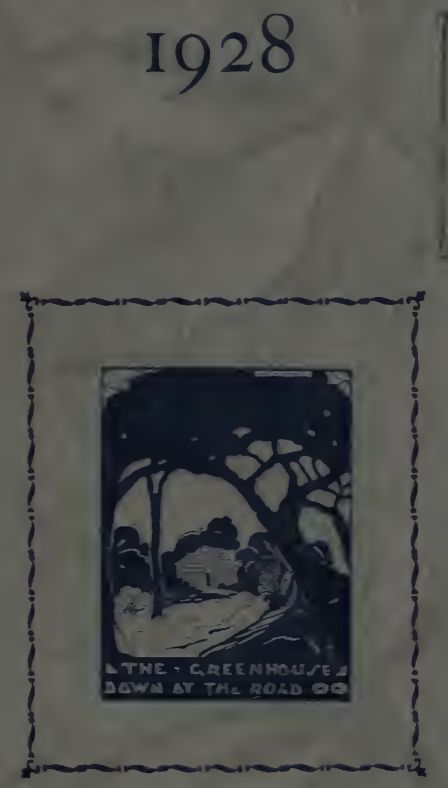





\section{Third Annual Catalogue}

\section{THE WHITE \& JOHNSON COMPANY \\ WAKEFIEI.D, MASSACHUSETTS}

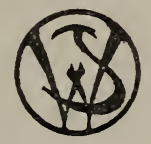

"The Greenhouses Down From The Road"

\section{FOREWORD}

Our friends will be surprised at the greatly increased size of our pricelist. To them, howerer, is due the increase and we thank them for it.

We heartily inrite one and all to risit us. Our perennial gardens alone will be well worth sereral trips of inspection this year. Our aim in this department is to proride a list that will include many of the rarer and more unusual plants. We hare already made plans to increase our list greatly the following year.

The "Shrubs and Trees" list has been radically changed in scope. We beliere that we hare compiled one of the most complete priced lists of this character to be found in our region. We wish it to be clearly understood that we do not grow the trees and shrubs ourselces, but merels procure them for our customers. With the connections we have established, we feel our customers will be thoroughly satisfied with any purchases from this group.

One entirely new department has been added, namely, "Fall Bulbs." The demand for these has increased tremendously with us. We sold out completely this last fall, although we sared many more out of our planting stock than erer before. As we publish but one large price-list a year, we are including them in our spring list. Our prices on some of these items are especially good, due to our light orerhead in connection with them.

Our purpose is to build an organization that can take care of our customers' complete horticultural and floricultural needs. We inrite you to gire us a trial order.

Visitors are welcome. We are glad to see you.

DONALD WHITE, President

WALTER W. JOHNSON, Treasurer.

PLEASE KEEP THIS PRICE-LIST. IT IS POSSIBLE THAT NEXT SPRING WE WILL DISTRIBUTE MERELY A SUPPLEMENTARY LIST. 


\section{Table of Contents}

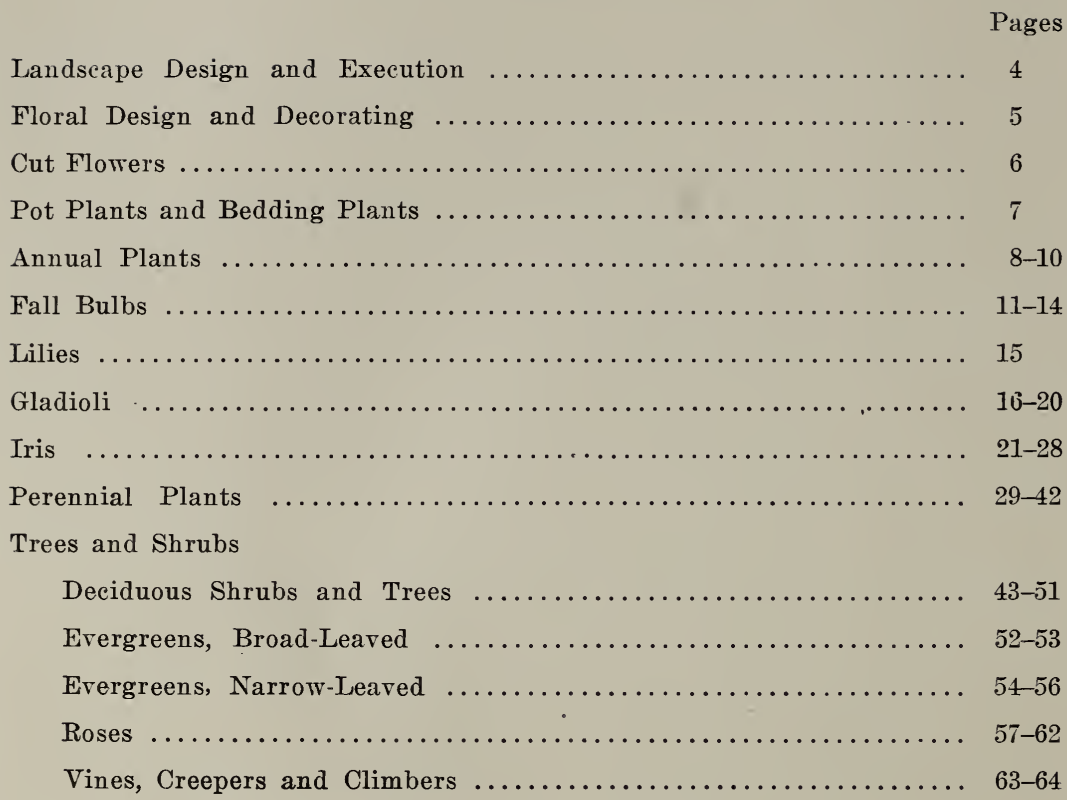




\section{General Directions}

Order in Time. This is particularly important in the spring and fall on account of the danger in planting many items too late in either season. Moreover, you are surer of obtaining your full list although we strive-even at a loss-to fill your orders at any time.

Forwarding. Most of our goods are sent by express, purchaser paying charges. Cut flowers and floral designs are sent by mail whenerer possible, purchaser paying postage. If customers desire plants or bulbs sent by parcel post, simply add ten per cent of order to payment.

Local Delivery. We give free delivery on all orders of one dollar or more in the towns of Wakefield and Stoneham, besides the Winchester, Melrose and Choate Memorial Hospitals, and the New England Sanitarium and Hospital. A delivery charge of fifteen cents is placed on all orders of less than one dollar in Wakefield and Stoneham.

Free delivery is provided on all orders of $\$ 5.00$ or more in all places within a ten-mile radius; on all orders of $\$ 10.00$ or more within a twenty-mile radius; and on all orders of $\$ 20.00$ or more within a thirty-mile radius.

In any cases not covered above, delirery charges are made according to distance and value of order.

IMPORTANT: The abore free delivery statements do not necessarily hold in regard to materials supplied for landscape work.

Errors. While we do not wish to make errors, we are but human. Therefore kindly inform us at any time-and immediately-of any error that may occur in any order.

Cash With Order. This is absolutely necessary except in the case of those who have regular accounts with us.

Non-Warranty. Customers realize, of course, that it is to our best interests to send out material of good quality. As so many accidents happen after goods are out of our hands, it is obviously impossible for us to guarantee our products in any way, shape or manner. We, therefore, give no warranty as to description, quality or productireness of any of the plants, bulbs or other materials we send out, and will not be in any way responsible for any results therefrom, and every order for articles named in this catalogue will be executed on these conditions only.

To Reach Our Place. Visitors coming from Boston should take the Fellsway to Stoneham, thence on the Wakefield road about one mile. Coming from the North Shore, come through South Lynnfield. Coming from the north, take the road to Reading from either Lowell or Lawrence; from Reading take the Quannapowitt Lake road to Wakefield, thence about one mile on the Stoneham Road. Visitors coming by train will find the following stations about equidistant from our place: Wakefield Junction, Wakefield Upper Station and Farm Hill (Stoneham). 


\section{Landscape Design and Execution}

We have had more of this type of work during the past year than we ever had before in toto. This year we wish to at least double that record.

If you have a new house it will cost you nothing to hare a talk with us about the probable cost of beautifying the grounds. It is in residence grounds that our interest settles.

We are prepared to DESIGN the home grounds, EXECLTE the design, and attend to the UPKEEP thereafter.

If you have FOUNDATION PLANTINGS that need ALTERATIONand how many have!-we will be glad to do this work for you.

PRUNING of fruit trees and shrubbery is very often neglected. Allow us to estimate on the cost of attending to this.

GRAFTING very often adds variety to the fruit of the home garden, or changes orer a worthless tree into an asset.

May we respectfully call attention of those LANDSCAPE ARCHITECTS who do not execute their own designs to the fact that we are always glad to submit estimates to them for such work. 


\section{Floral Design and Decorating}

It is one of our aims in floral work to produce original and unusual designs. Howerer, we wish it understood that all stock patterns will be made up for those who wish them.

The success of any social erent is always enhanced by the presence of the proper floral decorations, tastefully and skilfully arranged.

Wedding bouquets and decorations form a fascinating field of endearor. Here there is ample room for creative talent.

Among funeral designs there tends to be a general sameness. We try to break away from this and gire a unique and direrse line of material.

Presentation bouquets are capable of wonderful rariation. We give each one that indiridual eare that means satisfaction to the customer.

Table decorations are used much less than they could be. For a surprisingly small sum we will contract to keep your tables always alice and fresh with the beauty and fragrance of flowers.

Decorating for receptions, parties, and other functions is gladly undertaken. Estimates are promptly submitted for any particular place and event. 


\section{Cut Flowers}

We are prepared at all seasons to supply cut flowers at quick notice. The great bulk of our production goes to the Boston and New York markets, but more and more is being used in our retail work.

Our principal cut flower is the carnation. Of these we are growing over twenty varieties: our customers are thus assured of good variety. These may be sent a long distance by mail.

Other greenhouse cut flowers grown in our range are: Calendulas (large and small types, yellow and orange), Blue Daisies (Agathaea), Bouvardia, Swainsona, Erlangea, Sweet Peas, Snapdragon, Stevia, Chrysanthemums, Gypsophila (Baby's Breath), Forget-me-nots, Stocks, and Delphinium.

We force many bulbs each year. The principal ones are: Freesias in various colors; Tulips (Single and Double Early, Darwins, and Breeders); and Narcissi (Giant Trumpets, both Yellow and Bicolor, Incomparables or Medium Trumpets, Poetaz, Polyanthus and Double Flowering).

Lesser bulb crops are Hyacinths and Gladioli.

Orders for cut flowers of kinds other than those grown here will be executed as promptly as possible. We are so situated that we are able to supply roses in variety, violets and callas within one-half hour after order is received. Other flowers can be procured on request.

In spring, summer and fall, we have a wealth of outdoor flowers, both annual and perennial. Many beautiful assortments can be made up from these. 


\section{Pot Plants and Bedding Plants}

Geraniums constitute our chief item in this class of material. We carry rarious types and colors. Among the ordinary type we carry Annie Vincent, Buchner, Fiat, General Grant, Improred Poiterine, Madame Landry, Poiterine, Radio Red, Ricard, Rosalie, S. A. Nutt. Of the rariegated leared sorts we carry Happs Thought, Madame Salleroi, Mrs. Parker, Mrs. Pollock, Silrer-leaved S. A. Nutt. Irs geraniums are represented by the red Caesar Franck, the pink Rycroft Surprise and a rariegated leared rariety.

A short price list follows. Any kinds not represented here will be procured upon request. This list applies to spring planting trade only.

\section{AGERATUM}

\section{ALYSSUM, SWEET}

BEGONIA-Small-flowered.

BEGONIA-Tuberous-rooted, single, mixed double, mixed frilled, mixed

BELLIS PERENNIS (English Daisy)

\section{COLEUS}

COLEUS-Fanes rarieties.

CUPHEA (Firecracker or Cigar Plant)

GERANIUM-Standard rarieties

Iry leared

Madame Salleroi (white-edged)

LANTANA

Tariegated (except Salleroi)

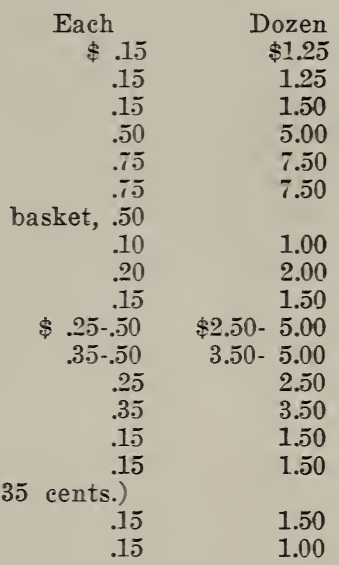

LOBELIA

PANSY (2 qt. basket, 25 cents; 3 qt. basket, 35 cents.)

PETUNIA, Portland-Tarious colors. Rosy Morn

We carry some of the abore items in larger sizes. 


\section{Annual Plants}

In this group we very naturally desire quality plants as we use thousands of them ourselves for cut flowers.

For the second year in succession our aster display won first prize at Horticultural Hall, Boston.

Although the demand for plants may have switched considerably to perennials, it is quite true that many persons are finding that a perennial bed takes fully as much time to keep in fine condition as an annual planting. They each have their place in good gardening practice.

Our list of ammuals is larger, we believe, than will be found in most establishments. Our stock, therefore, of some varieties is small and early ordering is advised.

We give prices in some cases, for both flatted and potted stock. Of course, the potted stock is easier to handle and is especially recommended if the plants are to travel any distance before they are planted.

ANTIRRHINUM (Snapdragon) - Large-flowering, half dwarf (about 18 inches). Choice mixed.

Per dozen

Flatted Potted

ARCTOTIS GRANDIS (African Daisy)-Very nice daisy-like flowers, white above and bluish beneath; the centers are steel-blue. 2 to 3 feet high. Blooms last a week or ten days in water.

ASTERS-We grow Queen of the Market, Royal, American Late-Branching, California, American Beauty, Single, and various odd rarieties.

$\$ .50 \$ 1.25$

BALSAM-An old favorite, producing gorgeous masses of brilliant-colored, double flowers in profusion. Finest mixed.

BARTONIA AUREA-For sandy soil. Large, brilliant yellow flowers, rery showy. 18 inches.

BROWALLIA-(Amethyst)-Elata mixed. Blooms profusely. Blue or white. 18 inches.

CALLIOPSIS CORONATA-Large, orange-yellow, spotted brown. 1 foot.

CELSIA CRETICA (Cretan-Mullein) - Large yellow flowers, spotted with brown, showy. Really a biennial but not hardy. 4 feet.

CENTAUREA IMPERIALIS (Royal Sweet Sultan)-Their odor, beauty, length and strength of stem, and ability to stand up for several days in good condition, make this a popular flower. Separate colors: Deep lavender, deep purple, delicate lilac.

CENTAUREA MOSCHATA (Yellow Sweet Sultan)-Lasts well. Showy, large, bright yellow blooms.

CENTAUREA MOSCHATA, The Bridegroom-Heliotrope color. Very fragrant.

CHEIRANTHUS ALLIONII (Wallfower)-Rich orange flowers in abundance. It is really a biennial but we are treating it as an annual. 18 inches.

CHRYSANThemUMS, Annual or Painted Daisies-Showy in the garden and excellent for cut flowers. Blooms single and daisy-like, quite distinct from the fall chrysanthemums. We grow several kinds, the colors being largely in the browns, yellows, reds and whites. 2 feet.

COSMOS, EXTRA EARLY COLOSSAL-Mixed colors.

EARLY DOUBLE-Mixed colors.

CYNOGLOSSUM AMABILE-A lovely flower, resembling a Forget-me-not. 
DELPHINIUM-The colors of the annual Larkspurs have a much wider range than the peremnial. Separate colors: Ageratum Blue, Lustrous Carmine, Exquisite (rose-pink)

DELPHINIUM AJACIS CAERULEUM-A bright indigo blue variety of the Rocket Larkspurs. Double. 30 inches.

DIANTHUS LACINIATUS, Salmon Queen-Bright salmoncolored. Fine double garden pink. 9 inches.

DIDISCUS COERULEUS (Blue Lace Flower) - Blooms from July to Norember. Pale lavender blossoms. 18 inches.

DIMORPHOTHECA AURANTIACA (African Daisy) - Very showy. Glossy rich golden-orange. The flowers close at night but are borne very profusely. A fine flower for mixed bouquets.

DIMORPHOTHECA EKLONIS-Star-shaped, white flowers. The disk is small and of a deep blue color. Nice for bouquet work.

EMILIA FLAMMEA (Tassel Flower)-A brilliant orange-scarlet color. The flowers resemble tassels borne on long stems. Worthy of a place in any garden. 18 inches.

GAZANIA LONGISCAPA-One of the composites. A freeflowering, beautiful annual. Golden brown color. 9 inches.

GILIA CORONOPIFOLIA-One of the phlox-worts. A rery pretty biennial grown as an annual. Color a rich and rare shade of red in tall graceful spikes. 3 feet.

GOMPHRENA (Globe Amaranth)-Flowers look like clorerheads and may be dried for winter use. This is one of the prettiest ererlastings in the garden.

HELIANTHUS CUCUMERIFOLIUS, var. EXCELSIOR - A "striking new strain of sunflowers, yellow with broad zones of red, brown, and purple, excellent to cut." Only 3 feet.

HELICHRYSUM MONSTROSUM (Straw Flower)-Double flowers. Very effective in the garden with their bright colors and one of the rery best of the Everlastings. We grow

the following rarieties:

Buttercup-Rich yellow.

Rose Carmine-Rich color.

Salmon-A rosy-salmon.

Silver Ball-White.

LUPINUS HARTWEGI-The annual lupins are attractire and graceful plants. They are excellent border plants and the flowers are very suitable for bowl arrangements. All of our annual lupins are pot-grown as they do not take kindly to transplanting. Hartwegi is blue and white. 30 inches.

PINUS HYBRIDUS ROSEUS-An attractive pink rariety. 30 inches.

LUPINUS LUTEUS-Pale yellow, sweet-scented. 30 inches.

LUPINUS MENZIESI (or Sulphureus)-Tery good. Fellow spikes. 18 inches.

MARIGOLDS, AFRICAN-Yellow and orange. Double. Though stiff and formal they are rery appropriate for certain locations. Two to three feet.

MARIGOLDS, FRENCH-Yellows and browns. Double mixed. Up to 12 inches.

MECONOPSIS PANiCULATA-The Golden Himalayan Poppy. -A glorious plant. While really a biennial, we are growing it as an annual. Potted plants only. 3 feet.

NEMESIA STRUMOSA, var. Orange Prince-"A strikingly lorely variety, producing myriads of flowers of the most vivid orange, extra fine." Not a hardy plant and must not be planted out early. Potted plants only. 9 inches.

NEMOPHILA AURITA-Purple flowers. Pretty spreading plant. 1 foot. 
PHACELIA VISCIDA-Deep blue, with speckled rose center. 1 foot.

PHLOX DRUMMONDI-Excellent for solid beds or massed in the border. Its colors seem to run the gamut of the rainbow. Grow with gladioli for a pleasing combination. Separate colors: Shell pink, scarlet and crimson.

SALPIGLOSSIS, LARGE-FLOWERING (Painted Tongue)A fine annual. From the middle of the summer until frost their attractive flowers are produced in a large and unusual range of colors. The cut flowers last well. Mixed colors. 24-30 inches.

SALVIA SPLENDENS (Scarlet Sage)-A favorite bedding plant with many people.

America-The earliest, the most free and the most continuous bloomer, of all the scarlet sages. 2 feet.

Splendens-Bright scarlet. 3 feet.

SCABIOSA (Mourning Bride) - A very beautiful annual, flowering until the hard frosts. The shades of color are delicate and exquisite. Very fine for cut flowers. Separate colors: Lavender-blue, crimson, rose, white.

SCHIZANTHUS (Butterfly Flower)--Blooming throughout the summer this is one of our most charming annuals. The flowers are very dainty and light and the foliage is finely cut. Mixed colors. 18 inches.

SENECIO ELEGANS (Groundsel)-Double flowers. Mixed colors. Half hardy.

STATICE SINUATA (= Limonium sinuatum), Notchleaf Sea Lavender, var. True Blue-An excellent everlasting. This is a highly improved form, navy blue in color. 15 inches.

STATICE SUWOROWI-Pretty bright rose flowers in large spikes. 18 inches.

STOCKS (Gilliflower)-A very popular annual. Colors are brilliant, blooms fragrant and profuse. "Cut-and-Come-Again" type.

SYMPHIANDRA HOFMANNI--One of the bell-worts. Really a biennial, but grown by us as an annual. Dense spikes of white bell-shaped flowers.

VERBENA-Here we have a range of brilliant colors; pink, purple, scarlet, white, blue and lavender. Good for massing in the border and are attractive as cut flowers.

XERANTHEMUM ANNUUM (Everlasting or Immortelle)One of the best everlastings, showy in the garden and useful for winter use. Bright rose, purple and white. Mixed colors. 3 feet.

ZINNIAS-Dreer's Special Strain of Giant Double. This is a fine old favorite and this strain is an excellent strain. Mixed colors.

ZINNIAS-Double Dahlia-Flowered. The latest development in zinnias. Flowers are large and resemble a decorative dahlia. 


\section{Fall Bulbs}

As noted in the forepart of this price-list our prices on many of the items in this section are especially attractire. While we do not carry many rarieties we feel that our selection is excellent.

\section{Darwin Tulips}

This is the most popular type of tulip.

Figures in parentheses represent the height in inches

AFTERGLOW (26)-Orange, shaded old rose.

BARTIGON (26)-Deep carmine, white center. Large. .05

Each Dozen

BLEU AIMABLE (24)-Bright violet; inside dark riolet-purple

A fine tulip.

CITY OF HARLEM-Red. Large.

CLARA BUTT (22)-Salmon pink. Choice.

FARNCOMBE SANDERS (26)-Fiery rose-scarlet. One of the largest Darmins.

FAUST (29)-Deep purple-black, blue base.

KING HAROLD (24)--Dark maroon scarlet. One of the best

LA TULIPE NOIRE-Very large

Le NOTRE (24)-Clear pink.

MME. KRELAGE (28)-Rose pink. Thrires well.

PRIDE OF HAARLEM (32)-Purplish red. Blue center.

PRINCE OF THE NETHERLANDS--Rose scarlet

PROF. RAUWENHOFF-Pale rosy red. Large.

REV. H. EWBANK (24)-Heliotrope lilac.

SCARLET BEAUTY (24)-One of the best scarlets.

.10

WHITE QUEEN (24)-Slightly tinged blush.

WILLIAM COPLAND (26)-Rosy lilac.

WILLIAM PITT (24)-Dark crimson. Large flower.

\section{Dutch Breeder Tulips}

"These are similar to the Darwins in many respects, being, if anything, eren more robust in growth and stature. Like the Darwins, they are mostly self-colored, but are noted for their peculiar dull, artistic color tones, which range through what artists call the 'pastel' shades. Many of them are distinctly sweet-scented." (Rockwell.)

BACCHUS (28)-Dark plum color; rery large flower.

Each

Dozen

DON PEDRO (21)-Coffee color.

FEU ARDENT-Mahogany red.

GOLDEN BRONZE-Old gold and bronze.

LOUIS XIV (30)--Dark purple flushed with bronze, with broad 


\section{Single Cottage Tulips}

"These come into bloom somewhat later than the single earlies; have much larger flowers; and grow taller. They include the widest range of colors and variations of flower forms of any of the sereral classes." (Rockwell.) Remember that yellow is lacking among the Darwins but is present in this class.

AVIS KENNICOTT (25)-Deep yellow.

$$
\text { Each Dozen }
$$

FAIRY QUEEN (20)-Rosy heliotrope, broadly margined yellow.

Large flowers.

$\$ .15 \$ 1.25$

GESNERIANA MAJOR (20)-Crimson scarlet with a blue-black center.

GESNERIANA LUTEA (24)-Golden yellow.

GRENADIER-Dazzling vermilion.

$\$ .10 \$ .65$

INGLESCOMBE YELLOW (22)-Pale yellow.

JOHN RUSKIN (18)-Pink, bordered golden.

MRS. MOON (24)-Pure yellow.

SNOWDOWN-Pure white.

$\begin{array}{ll}.10 & .65 \\ .05 & .60 \\ .10 & .75 \\ .05 & .50 \\ .10 & .75 \\ .10 & .90 \\ .10 & .75\end{array}$

\section{Single Early Tulips}

"These are the first to flower. They include the most brilliant colors to be found among tulips."

DUC de BERLIN-Red and yellow.

FLAMINGO-Deep rose.

Each Dozen

$\$ .10 \$ \frac{.70}{10}$

FRED MOORE (20)-Bright orange, shaded scarlet. Sweet scented.

IBIS (Tall)-Deep brilliant pink.

KEIZERKROON (Tall)-Crimson scarlet, edged yellow.

KING OF THE YELLOWS-Golden yellow.

$.10 \quad .70$

PINK BEAUTY-Deep rose, center white and yellow.

WOUWERMAN-Dark violet.

$.10 \quad .70$

$.10 \quad 1.10$

$.10 \quad 1.00$

$.10 \quad .80$

$.15 \quad 1.25$

$.10 \quad .75$

\section{Double Early Tulips}

"The double form of the early tulips is entirely different from the singles, the blooms much resembling a small peony in appearance. The flowers last considerably longer than the singles. They come somewhat later, do not arerage as tall in growth and are less brilliant in coloring." (Rockwell.)

CROWN OF GOLD-Pure yellow

ELECTRA-Deep violet, shaded light riolet.
MURILLO-Blush pink shaded white.

Each Dozen

$\$ .10 \$ .80$

$.10 \quad 1.00$

PEACH BLOSSOM-Rose pink, flushed white. Large flower. $\quad \begin{array}{rr}.60 \\ 10\end{array}$

VAN der HOEF-Pure yellow sport of Murillo.

$.10 \quad 1.10$

\section{Hyacinths \\ Bedding Size}

We do not carry the larger sizes both on account of the price and the fact that this is the largest size fitted for outdoor work in our climate.

GRAND MAITRE-Dark lavender-blue.

L'INNOCENCE-Pure white.

Each Dozen

QUEEN OF THE BLUES-Light silvery blue.

$\$ .20 \$ 2.00$

$.20 \quad 2.00$

QUEEN OF THE PINKS-Bright rose-pink.

ROI DES BELGES-Dark scarlet.

YELLOW HAMMER-Golden yellow. 


\section{Narcissi or Daffodils}

Please bear in mind when ordering from this group that the ierm "jonquil" refers to a narcissus with terete leares and sereral-flowered stems. The common daffodil is not a jonquil. Our classification folloms that of "The Book of Bulbs:" by F. F. Rockwell.

\section{DIVISION I}

Trumpet daffodils: Trumpet as long as or longer than petals. Doublenosed bulbs: Doz. $\$ 2.00$, unless otherwise stated.

A. Yellow Trumpet

EYPEROR-Large flower. Exellent.

GOLDEX SPLR-Early and free-flowering.

C. Bicolor Trumpet.

EMPRESS-Strong plant with large flowers.

GLORY OF SASSENHEIM (Improved Victoria)-Fine. (\$2.25.)

VICTORIA-A splendid rarietr.

\section{DIVISION II}

Incomparable or Large-cupped, the cup being less than the length of the petals, but at least one-third as long.

A. Petals, rellow: cups with or without red.

HOMESPLY-Beautiful rellow, and nicels shaped. Double-nosed bulbs; dozen \$1.75.

SIR WATKIX-Cup rellow, tinted bright orange. Double-nosed bulbs; dozen \$1.

\section{DIVISION III}

Barri, or Short-cupped rarieties, the cup being less than one-third as ?cng as the petals.

A. Petals rellow.

BARRI CONSPICLOUS-Cup conspicuously edged bright orangescarlet.

Dozen, $\$ 1.50$.

\section{DIVISION IV}

Leedsi, large-cupped and short-cupped flowers with white petals, and cup white, cream, or primrose.

MRS. LANGTRY-Broad white petals, with crown edged rellow, rery conspicuous and free blooming.

Dozen. $\$ 1.25$.

\section{DIVISION VII}

flowers.

Jonquilla and Jonquilla Hrbrids: clustered, fragrant, small bright rellow

CAMPERNELLE RUGULOSUS, GIANT SINGLE-The real jonquil. Double-nosed bulbs.

Dozen, \$1.00.

\section{DIVISION FIII}

Tazetta and Tazetta Hrbrids (Poetaz). The polyanthus or bunchflowered daffodils, three or more flowers to each stem. Fot hardy in our region.

LAURENS KOSTER-White with rellow ere. Fine producer.

Double-nosed bulbs. Dozen, \$1.75.

PAPERWHITES-The rers popular home forcing daffodil.

Dozen. \$1.25.

\section{DIVISION IX}

Poeticus: Snow-white petals; shallow cup or ere; rellow edged crimson or scarlet (sometimes all crimson or scarlet), and sweet scented.

POETICUS-True Poet"s Narcissus. Pure white with orange-red cup. Dozen, $\$ 1.00$.

POETICUS ORNATUS An improred form of the abore. Dozen. \$1.25.

\section{DIVISION $\mathrm{X}$}

Double rarieties.

ORANGE PHOENIX-Fellow and orange. Double-nosed bulbs. Dozen, $\$ 1.50$. 


\section{Miscellaneous Bulbs}

\section{CHIONODOXA (Glory of the Snow)}

A handsome dwarf blue spring flower.

SARDENSIS-Rich deep blue.

Dozen

$\$ .60$

\section{CROCUS}

BARON V. BRUNOW-Dark blue.

$\$ \quad .50$

MONT BLANC--White.

PURPUREA GRANDIFLORA-Dark purple.

SIR WALTER SCOTT-Large white, lilac striped.

LARGE FLOWERING MIXTURE

\section{ERANTHIS HYEMALIS}

(Winter Aconite)

GOLDEN YELLOW-6 inches. Plant in shrubbery or woody locations.

\section{GRAPE HYACINTHS}

(Muscari)

Plant in masses.

HEAVENLY BLUE-The largest and best.

SCILLAS, ENGLISH BLUEBELLS

SIBIRICA-In lawns, rock gardens, or planted among tulips and hyacinths 


\section{Lilies}

This class of plants is becoming more and more popular. It is worthr of representation in erery garden.

AURATUM (Goldband Lily)-The best known rariety. White

Each Dozen with gold bands and spotted maroon. $3 \frac{1 / 2}{1 / 2}$ to 6 feet. JulyAugust.

AURATUM PLATYPHYLLUM-The largest auratum. Broader petals and spotted rellow.

BATEMANNIAE-Apricot. 3 feet. July-August.

CANDIDCM (Madonna Lily)-Pure white. 3-4 feet. JuneJuly.

HANSONI-Deep rich orange rellow, spotted brown.

HENRYI (The Orange Speciosum)--Rich orange with green bands. 5-6 feet. Julr-August.

REGALE- White, rellow in throat; outside of petals shaded pink. 3-5 feet. Juls.

SPECIOSUM MAGNIFICUM-Rich carmine on white ground with crimson spots. $\$-5$ feet. August-September. 


\section{Gladioli}

A comparison with our list of last year will show that we have doubled the number of catalogued rarieties. This brings us closer to our self-imposed limit of one hundred rarieties. We see no practical use in carrying more.

Our stock on many kinds is limited. We have some of the best kinds represented and are growing others that will appear in our later lists. Certain descriptions are taken from the Cornell Extension Bulletin No. 11, "Varieties of the Garden Gladiolus" by Alfred C. Hottes. The entire original description is never used. Where figures such as (153 TV) are given after a color, it refers to the Plate and Shade of the Répertoire de Couleurs, which is accepted by the Color Chart Committee of the American Gladiolus Society. In this particular case the reference is to Plate 153 , Shade $I V$.

Prices are per dozen, and are for No. 1 bulbs unless otherwise specified.

Cat.

No.

252 ALBION-(Kunderd)-CTall. Large blossoms of salmon-rose with pinkish tinge. Primulinus.

Price, $\$ 1.50$.

201 ALICE TIPLADY-One of the most popular of the Primulinus type. Orange self-color (lower petals lighter).

Price, $\$ 1.00$.

253 ALICIA-(Kunderd)-Tall, brilliant orange-salmon with lighter throat. Many large flowers open at a time. Not a common variety. (Triangle Farms.)

Price, $\$ 2.00$.

254 AL SHIRA-(Kunderd)-Large flowers a rery dark wine red; throat almost black. Rounded petals. No. 2 bulbs.

Price, \$1.25.

202 AMERICA-(Childs)-Large. Perianth lavender-pink, a-more rosy tint of maure-rose $(153 \pi)$, the color blending to almost white as it approaches the throat; the throat marked with Tyrian Rose (155-III). A delicate color, well formed. Not as good substance as that of Panama. (Hottes.)

Price, $\$ 0.50$.

255 ANAMOSA-(Kunderd)--Primulinus. Orange-salmon, with golden throat. No. 2 bulbs.

Price, $\$ 1.25$.

256 ANGOLA-(Kunderd)-Primulinus. Soft salmon-pink.

Price, \$1.50.

257 ARLON-(Kunderd)-Bright orange-salmon with red throat. Strong

spikes. Primulinus.

Price, $\$ 2.50$.

258 ATHERTON-(Kunderd)-Deep salmon-rose, petals bordered with blue. Price, $\$ 1.25$.

2.59 BEST VIOLET-(Kunderd)-Tall. Many flowers open at one time. Reddish violet with fine gold lines.

Price, $\$ 1.00$.

260 BETTY DARNELL-(Kemp)-Light canary yellow shading to golden yellow in throat. Flowers large; several open at once. No. 2 bulbs. Price, $\$ 1.75$.

261 BLOOD SPOT-(Kunderd)-Perianth antique red (104-I) thickly feathered and flaked with near dull purple lake (170-IV). Lower segments with lemon-yellow throat blotehed and bordered by French purple (161-IV). A dull color. Eight blooms open at one time. A large number of blooms (25). Very rigorous. (Hottes.) Price, $\$ 2.50$.

262 BORDEAUX-(Alkemade)-Deep wine color. Price, $\$ 1.00$.

263 BRONZE BEAUTY-(Gage)-A beautiful gladiolus. No. 2 bulbs. Price, $\$ 2.00$. 
$26 \pm$ BUNKER HILL-(Metzner)-Crimson. Lower petals eorered with bright rellow. Flowers large and showr.

Price, \$9.00.

265

266

265

268

269

207

208

BLTTERFLY-(hunder
Price, $\$ 1.00$.

CAPELLA-(Kunderd)-Clear reddish orange. Primulinus. Price, \$0.75.

CARMEN SYLVA-(Prestgard)—Snow white blooms. No. 2 bulbs. Price, \$1.25.

CHAMELEON-(Purple)—Smoky changeable silk. No. 2 bulbs. Price. \$3.50.

CORLNNA-(Kunderd) - A strikingly unusual flower. The soft garnet red blossoms are large with widelr-spreading. pointed petals. Large, almost coal-black blotches bordered with white, combine to make this an extraordinary fiower. (Triangle Farms.) Price, $\$ 1.50$.

CRIMSON GLOW-(Betscher)-One of the best scarlets Price, $\$ 1.00$.

CRYSTAL WHITE-(Baer)-Medium size. Perianth white, blotehed with Trrian rose (155-I ). Compact bloom of good substance. Fire blooms open at one time. (Hottes.) Price, \$0.50.

DR. R. T. JACKSON-(Fischer)-Deep, rich, relrety red. Price, $\$ 1.00$.

EARLY SNOWFLAKE-(Kemp)-Rich, creams white with tinge of yellow in throat. Price, $\$ 1.00$.

E. J. SHAYLOR-(Kunderd)-Pure, deep rose-pink. A splendid rariets. jo. ? bulbs. Price, $\$ 0.75$.

ELBERTON-(Kunderd)-Fine, light, creams rellow, butterfir-shaped flowers; deeper in the throat; tall, graceful stems. One of the best in its color. (Triangle Farms.) Primulinus. Price, \$1.00.

ENIGMA-(Kunderd)-Striped red, white and bluish. A unique gladiolus. Price, $\$ 5.00$.

EVELYY KIRTLAND-(Austin)-Geranium pink, shading to pale pink. Lower petals blotched brilliant scarlet.

Price, $\$ 0.75$.

FAIRLAXD-(Kunderd)-Fine ruffled rermillion scarlet. Price, $\$ 4.00$.

FIRE RIBBON-(Kunderd)-Many blossoms open at once. Strikingly shomy. No. 2 bulbs.

Price, \$1.75.

FRECKLES-(Purple) - I bizarre creation. Red and sellow striped. Primulinus.

Price, \$0.75.

276 FREDA-(Salbach)-Tery large wide-open flowers of geranium pink, shading to La France pink in the throat. Cream-colored throat. Tigorous grower. (Triangle Farms.)

Price, $\$ 1.50$.

212 GAIETY-(Kunderd)-Medium size. Perianth light scarlet ( $8-I$ - $)$ splashed with deeper scarlet ( $87-I V)$, the lower segments more thicklr splashed. A pure white throat blotched and penciled with crimson-red (11t-III). Good open bloom of striking color and excellent substance. Attractire. (Hottes.)

Price, $\$ 1.00$.

278 GEN. PERSHING-(Kirchhoff)-Cpper part of perianth pale salmon pink; lower part rellow marked with carmine. No. 2 bulbs.

Price, \$1.25. 
279 GOLDEN KING-(Black)-Perianth lemon-yellow (21-I) with blotehes of blood red (93-IV). Color a trifle darker than that of Golden Queen. Blooms face several directions. Often double. Compact bloom. Excellent substance. A fair number of blooms (15). (Hottes.)

Price, $\$ 1.00$.

280 GOVERNOR HANLEY-(Kunderd)-Rich cardinal red, deeper in the throat.

$$
\text { Price, } \$ 1.50 \text {. }
$$

216 GRETCHEN ZANG-(Austin)-Vinaceous pink shading lighter. Scarletred bloteh on rose ground.

Price, $\$ 0.50$.

217 HALLEY - (Velthuys)-Large (11 cm.) wide. Perianth madder lake (122III) with fine stripes and dots of Tyrian rose (155-IT) on a lemon-yellow throat. Though it is catalogued as salmon, it has considerably more of a pinkish appearance. An attractive color. Substance excellent; and bloom compact. Four or five blooms open at once. (Hottes.)

Price, $\$ 0.50$.

218 HELEN FRANKLIN-(Kunderd)--White ruffled. Purple featherings on lower petals.

Price, $\$ 0.50$.

219 HERADA-(Austin)-Magenta shading to pink in throat. Rose blotch on lower petals.

Price, $\$ 1.00$.

281 JACK LONDON-(Diener) - Light salmon with brilliant orange flame stripes. Throat is a golden yellow. No. 3 bulbs.

Price, $\$ 1.50$.

282 JUNO-(Coleman)-Primulinus. Fine. No. 2 bulbs.

Price, $\$ 2.00$.

220 LE MARECHAL FOCH-(Van Deursen)-Large, pale pink. Small old-rose stripe on lower petals.

Price, $\$ 1.00$.

283 LILLIAN-(Kunderd)-Perianth amber-white (12-I) blotched with luminous blood-red (93-I), the upper segments suffused with a color pinker than crushed strawberry (109-III). Good compact bloom of medium substance. Five blooms open at one time. A fair number of blooms (14). (Hottes.)

$$
\text { Price, } \$ 2.00 \text {. }
$$

284 LINTON-(Kunderd)-Upper petals salmon-rose; lower petals yellow. Tall and well ruffled. (Triangle Farms.) Primulinus.

$$
\text { Price, } \$ 2.75 \text {. }
$$

221 MAIDEN'S BLUSH-(Grullemans)-Pink, mottled darker. Lower petals have a small erimson bloteh on purplish-yellow ground. Primulinus. Price, $\$ 1.00$.

222 MONA LISA-(Kunderd)-Palest soft rose-pink, or blushed white. Price, $\$ 2.00$.

285 MOTTLED BEAUTY-(Kunderd)-Large, intensely ruffled blossoms of light pink, heavily flaked and mottled with carmine. (Triangle Farms.) No. 2 bulbs.

Price, $\$ 6.00$.

223 MRS. DR. NORTON-(Kunderd)-One of the best. La France pink shading to very pale pink throat. Lower petals have creamy bases with carmine marking.

$$
\text { Price, } \$ 1.00 \text {. }
$$

224 MRS. FRANCIS KING-(Coblentz-Vaughan)-Large. Perianth rermilionred ( $87-\mathrm{II})$ sparsely splashed with deeper vermilion-red (87-III), and often penciled to form a blotch on two lower segments of vermilion-red. Bloom well open and the standard of substance; shape excellent; and the color clear. Six blooms open at one time. (Hottes.)

Price, $\$ 0.50$. 
225 MRS. FRANK PENDLETON-(Kunderd)-Large. Perianth rosy pink (118-I-II) with a large ox blood red (94-II) blotch. Excellent color, good size, good substance, well arranged. Four or five blooms open at once. (Hottes.)

$$
\text { Price, } \$ 0.75 \text {. }
$$

226 MRS. WATT-(M. Crawford)-Medium size. Perianth crimson-red (114III) with a lighter medial line on lower segment, and a light base of inferior, lower segment. The color is an excellent deep red. Blooms have good substance and are well arranged on a neat spike. Four blooms open at once. (Hottes.)

$$
\text { Price, } \$ 1.00 \text {. }
$$

286 MRS. WILLIAM KEN'T-(Diener)-Light rosy fawn, lightly striped with rose-pink. Old rose in the throat. Many blossoms open at one time. (Triangle Farms.) Price, $\$ 1.25$.

249 MYRA-(Metzner)--Rich salmon on yellow ground. Price, $\$ 1.00$.

227 MYRTLE-(Kunderd)-Shell pink. Price, $\$ 1.00$.

287 NETHERLANDS-(Barret)-Salmon rose. Lower petals feathered with ruby color.

$$
\text { Price, } \$ 1.00 \text {. }
$$

230 ORANGE GLORY-(Kunderd)-Very rich orange ruffled. Price, $\$ 1.00$.

231 PANAMA-(Banning)-Large. Perianth lavender-pink, a little more rcsy tinted than mauve-rose (153-IV), the color becomes almost white in the throat. Lip marked with Tyrian rose (155-III), not quite so decided as in America. The color is slightly darker than that of America, and the substance is better. (Hottes.)

$$
\text { Price, } \$ 0.50 \text {. }
$$

232 PEACE-(Groff)-Perianth white, usually lilacy white (7-I), each of the lower segments striped with violet-rose (154-IV), the upper often suffused and penciled with violet-rose (154-I). A dainty color. A large number of blooms (22). (Hottes.)

Price, $\$ 1.00$.

250 PEARL, THE-(Westerbeck \& Klyn)-Clear, soft pink turning to light cream in center.

Price, $\$ 1.00$.

PEARL OF DAWN-(Kunderd)-Bright rose pink blossoms with the color deepening toward the edges. Center lighter with large red throat markings. (Triangle Farms.)

Price, $\$ 4.50$.

PRIMULINUS HYBRIDS-(Mixed)--No. 2 bulbs.

Price, $\$ 0.25$.

234 PRINCE OF WALES-(Van Zanten)-Strawberry pink shading to a very pale pink throat. Faint scarlet bloteh on lower petals.

Price, $\$ 1.00$.

289 PRINCESS OF ORANGE-(Kunderd)-Perianth russet-orange (82-IVreally brighter), throat lemon-yellow, rounded with a pointed dart forward and bordered with a carmine-like coloration. A good bright-colored variety. A fair number of blooms (18). (Hottes.)

Price, $\$ 1.00$.

236 PURITY-(Purple)-White. No. 2 bulbs.

Price, \$0.50.

290 RED COPPER-(Kunderd)-Large flowers of deep rosy salmon, heavily flaked blue. A very unusual combination of colors and greatly admired. (Triangle Farms.) No. 2 bulbs. Price, $\$ 1.75$.

291 ROANOKE-(Kunderd)-Yellow primulinus hybrid.

- Price, $\$ 0.75$. 
292 ROSEMARY-(Wing-Bales)-White, thickly marked with fine parallel hairlines and stiplings of lavender-rose. The markings are carried clear through the petals. Sereral open at one time. (Triangle Farms.) Price, $\$ 2.50$.

ROSY GLOW-(Kunderd)-Rose-pink on white ground.

$$
\text { Price, } \$ 1.50 \text {. }
$$

240 ROUGE TORCH-(Groff-Tracy)-Perianth amber-white (12-I) thickly suffused with salmon-carmine (125-I) blotched with deep carmine-red (114IV). A compact bloom of good color and substance, well arranged on spike. Four blooms open at one time. A fair number of blooms (11). Two spikes per corm. (Hottes.)

$$
\text { Price, } \$ 1.00 \text {. }
$$

241 SALMON BEAUTY-(Kunderd)-Deep salmon, with rich salmon-yellow throat. A primulinus.

Price, $\$ 1.00$.

293 SENTINEL-(Kunderd)-Rose pink with white penciled throat. Tall. No. 3 bulbs.

Price, \$0.50.

294 SENECA-(Kunderd)-Primulinus. Delicate yellow faintly tinged with pink. No. 3 bulbs.

Price, $\$ 0.50$.

295 SIRIUS-(Metzner)--Dark salmon with brighter throat. Short. No. 2 bulbs. Price, $\$ 0.50$.

296 STARBRIGHT-(Bales)-Beautiful daffodil vellow blossoms with a broad and distinct band or stripe of rose through the center of each one of the six petals. Sereral open at one time. (Triangle Farms.) Price, $\$ 9.00$.

SULPHUR GLOW-(Kunderd)-Ruffled. Soft yellow. No. 2 bulbs. Price, $\$ 1.50$.

298 SUNSET GLOW-(Childs)--Orange scarlet primulinus hybrid. No. 2 bulbs. Price, \$0.75.

299 THEDA-(Purple)--Shrimp pink with soft yellow throat. Tall. No. 2 bulbs. Price, $\$ 1.75$.

300 TYRIAN BEAUTY-(Kunderd)-American Beauty. Rose color. Price, $\$ 1.50$.

301 UNUSUAL-(Kunderd)-Peculiar red shade with lower petals darker. A veining of white sometimes appears. Price, $\$ 1 . \overline{0} 0$.

VIOLET BEAUTY-(Kunderd)-Cerise violet with large red blotehes in throat.

303 WANETA-(Kunderd)-Ruffled primulinus hybrid. Rose pink with throat a creamy white.

Price, $\$ 2.25$.

243 WILBRINCK-(Hopman)-Tery early. Pale pink, upper petals tinted slightly darker. Lower petals have a light amaranth purple bloteh on a yellowish ground.

Price, $\$ 0.75$.

244 YOUELL FAVORITE-(Kunderd)-Larender-pink.

246 MIXED.

Price, $\$ 1.00$.

Price, $\$ 0.50$. 


\section{Iris}

This wonderful group of plants is listed apart from our other perennials because it is so much of a specialty flower and because we are listing so many varieties. to time.

More good kinds are on the way and will appear in our lists from time

Descriptions marked "Sand" in parentheses are taken from the Cornelı Extension Bulletin 112, by Austin W. W. Sand or from Memoir 100 of the Cornell Agricultural Experiment Station, written by the same author. Each description is necessarily a shortened form of the original.

Several terms used in certain descriptions are here defined (from Cornell Extension Bulletin 112).

Self-standards and falls of apparently the same color, and unmarked.

Plicata-standards marked. The ground color variable, the markings also variable, sometimes bronze, but never yellow.

Veined bicolor-venation present in blade of falls. Ground of any color, venation red or purple toned, sometimes bronze, but never yellow.

Velvety bicolor-usually, but not always, due to veins becoming confluent on the fall.

Solid bicolor-colors often blended, but rarely dominantly yellow.

Unless otherwise noted, the dozen price is ten times that of an individual. $\mathrm{S}=$ Standards. $\mathrm{F}=$ Falls.

Cat.

No.

49183 AFTERGLOW-Color effect a smoky lavender-buff and yellowish bronze blend. Fair-sized rounded blooms, freely produced. In gardens it reaches a height of three to four feet, bearing its flowers well above the foliage on graceful stems. It is exceptional for its bewitching color mass in twilight hours and for its delicate lemon odor. This variety is very effective as a cut flower. (Sand.) 50 cents each.

40889 ALCAZAR-Color effect light hortense violet, velvety pansy-violet bi-color. A large, well-balanced flower of extra substance, firm texture, and good fragrance. An outstanding specimen plant, with excellent foliage. (Sand.) 35 cents each.

40994 AMBASSADEUR-Color effect a smoky bronze, dark velvety maroon bicolor blend. An exceptionally tall, widely branched, and late bloomer. It is unexcelled in its class for size of bloom. (Sand.) $\$ 1.00$ each.

46083 AMBIGU-Color effect a bright smoky red, velvety blackish purple bicolor. The medium height of this variety and its wealth of intensely colored blossoms build up well in mass plantings. It has dwarf compact foliage and is outstanding for its strong elder fragrance. (Sand.)

$\$ 1.00$ each.

41083 ARCHEVEQUE-Color effect a deep violet to velvety purple self; size fair to good; form short to long, compact, rounded; flowering habit moderately free; tall bearded class; height 24 in. A flower of good substance; firm texture; little fragrance; good lasting quality. Of excellent color for a specimen clump, mass planting, or a eut flower. The faults of this variety are its slow increase and an occasional poor season of flowering but its intense color and rich texture repay the grower who demands this scarce iris. (Sand.)

35 cents each.

46194 BALLERINE-Color effect a blue and violet bicolor; size large; flowering habit moderately free; height 27-42 in. A flower of good substance; frail to firm texture; very good fragrance; good lasting quality. Useful in clump or landscape, and fair as a cut flower. One of the most strongly scented irises. Perhaps a hybrid of Amas. (Sand.) $\$ 1.00$ each. 
46291 BRANDYWINE-Standards and falls pale silvery blue; distinct orange beard. The general color effect of the flower is clear chinablue. In some respects it is similar to Crusader, but pronounced by those who have seen it to be far superior. (Farr.)

$\$ 1.00$ each.

BRIDE-Color effect a white self; size small; flowering habit free; height 8 in; not branched. A flower of medium substance; good fragrance; medium lasting quality. The slight tinge of green noticed when the flower is first open fades to white. Good in mass. It is rather a delicate grower, and is best suited to protected situations which are well drained. (Sand.)

25 cents each.

46475 CAPRICE-Color effect a red-purple self; size good; flowering habit free; height 18-24 in. A flower of medium good substance; a fine grape-juice odor; good lasting quality. A flower of good form and excellent fragrance. Useful as a cut flower or in general garden mass. A good red-purple iris, perhaps of pallida origin, and worthy of a place in every garden. It is rated too Iow for its color and freedom of bloom. (Sand.)

25 cents each.

46581 CARTHUSIAN-Color effect a clear bluish lavender, darker blue, bicolor; size large; flowering habit free; height $30 \mathrm{in.} \mathrm{A} \mathrm{flower} \mathrm{of}$ good substance. An early large-flowering fragrant variety, best in mass but useful as a cut flower or in specimen clumps. (Sand.)

50 cents each.

413 CECIL MINTURN--A uniform soft shade of cattleya-rose. A free bloomer. One of the best and largest pink-toned varieties available for mass effect. $\$ 1.00$ each.

400 CHARLES DICKENS-Color effect a light violet self, veined with deep violet; height 24 in. A flower of medium substance; firm texture. Interesting for its many flowers on a stalk and its slender leaves. (Sand)

25 cents each. $\$ 2.00$ a dozen.

45069 CHESTER J. HUNT-Standards celestial blue. Falls dark marine blue, bordered pale blue. A beautiful Iris. 50 cents each.

41480 COL. CANDELOT-Color effect a maure fimbriated with golden reddish brown, rich plum, bicolor; size small to fair; height 30 in.; medium lasting quality. The blooms are interesting on specimen plants, and are perhaps useful as cut flowers. Recommended by the introducer as a good variety of first-rate decorative quality for grouping. The intense coloring of the falls is of a rich velvety sheen, and the spathes are strikingly inflated. (Sand.)

50 cents each.

41587 CRUSADER-Color effect a light violet bicolor approaching a self; size large; height 27 in. The bold clear color is interesting on specimen plants or in well-established mass plantings. The growth is best in heavy soils, where the plants yield a wealth of bloom. (Sand.)

50 cents each.

45180 DALILA-Color effect a cream-white, violet-red-bronzed, bicolor; height $24 \mathrm{in.}$ It is interesting for its striking soft colors of fleshcolor and rich dahlia purple, which make it good as a cut flower and give a low-intensity color in mass. Received a certificate from the National Horticultural Society of France. (Sand.)

50 cents each. 
41675 DALMARIUS-Color effect a lavender and gold, blended self; height $32-36$. It is equal to any pallida for niass or as a cut flower. The color is delicate and subdued, but is set off by the brilliant beard, and the whole plant is graceful. One of the best rarieties for the landscape gardener. It has a long period of effective bloom. The rating is too low. (Sand.) 25 cents each.

417 DEJAH-A Perry seedling. Magnificent tall-growing rariet5. $4 \frac{1}{2}$ feet or more. Standards dark silver-blue. Falls bright maure-blue. Bold yellow and white beard.

$$
\$ 2.00 \text { each. }
$$

46691 DOMINION-The most richly colored of all the Dominion race and the outstanding member because of the extraordinary derelopment of the falls. Standards light bluish riolet, large, erect and of good breadth. Falls deep rich indigo purple relvet, well expanded and of exceptional substance. Pronounced orange beard. 30 in. (Salbach.) $\$ 7.50$ each.

467 EDEN PHILPOTTS-Color effect a light riolet self; height 36 in. Useful as a specimen plant because of its height, as a cut flower because of the attractireness of its well-spaced blooms. The large flowers are well shaped and of a color approaching a cool steel-blue hue. (Sand.)

50 cents each.

41874 ETTA-Color effect a light yellow self; height 10-15 in. Useful in mass or specimen clump. Its numerous large flowers are of good form and delicately colored. Darker than King Christian, and rery good for mass color effect. (Sand.)

25 cents each.

4 2 80 FAIRY-Color effect an opalescent blue-white self; height 27 in. An excellent white eut-flower type, with delicate tints of pallid blue, bluish crests, and a broad, showr, yellow beard. Deliciously and hearily scented. Deserres much wider popularity. (Sand.) 2 j cents each.

468 FEDORA-Flowers large and of perfect form. S. old gold; F. rich, deep, reddish riolet purple, broadly edged gold, rich colors, producing a striking effect.

$\$ 2.00$ each.

40170 FLAVESCENS-Color effect a light sellow self; height 20-27 in. An early sort, useful in mass and for cut flowers. It is rated too low, since there are no better sorts to take its place for early mass effects. (Sand.)

$2 \tilde{\text { cents each. }}$

41976 FLORENTINA ALBA-Color effect a somewhat grayed bluish white self; height 27 in. Useful in mass, where its persistent foliage is good after the flowering season is over. Useful also as a cut flower. For a rariety so well adapted to general mass plantings and so useful as a cut flower, its rating would seem much too low for an iris of its quality, produced early in the season. (Sand.) 25 cents each.

42074 FRITJOF-Color effect a pale violet and relrety purple bicolor; height $22 \mathrm{in.} \mathrm{Tseful} \mathrm{in} \mathrm{clumps,} \mathrm{as} \mathrm{a} \mathrm{cut} \mathrm{flower,} \mathrm{and} \mathrm{for} \mathrm{garden} \mathrm{effect.}$ A vigorous and free-blooming plant, of intermediate season in flowering. (Sand.) 25 cents each.

469 FULVA--Tery distinct and quaint, reddish copper color. Likes a damp location. 18 in. (Pudor.) 35 cents each.

470 GEORGE YELD-This is one of the finest Iris which Perry has produced. It is absolutely a new combination of colors and is magnificent and absolutely distinctire. Stout branching stems bear large well-shaped flowers. S. bright apricot shaded rose; F. brilliant rose crimson edged buff. (Quality Gardens.) $\$ 7.50$ each. 
42189 GEORGIA-Large flowers of a uniform soft shade of eattleya-rose. One of the best pinks.

75 cents each.

492 GYPSY QUEEN--Color effect an old gold, velvety maroon veined bicolor. Its very late bloom, its dull color combinations like those found in the Cypripedium orchid, and its early history, being a parent of the variegata groups, make it still worthy of selection. (Sand.)

25 cents each.

471 H. CRAMER-A blue of moderate height.

25 cents each.

42273 HER MAJESTY-Color effect a mallow pink, light mallow purple self, slightly blended and veined. The good-sized, fragrant blooms are borne on rather heavy, stiff stems. Its color is pleasing, and the firm texture of the blooms makes it a good cut flower. As a distinct pink and a late mid-season bloomer, it is still worthy of a place in any garden. (Sand.)

25 cents each.

472 HERMOSA-A large strong flower with stout stems. Very bright pink. The liveliest, brightest, most brilliant pink in the garden. (Quality Gardens.) $\$ 1.00$ each.

40240 HONORABILE-Color effect, a yellow, red-brown bicolor. The plant is a vigorous grower, producing many small to fair-sized flowers. The newer variety, Fro, is much preferred today, though many still retain Honorabile for its color contrasts and its historic past. Rating is too low at 40 . (Sand.)

25 cents each. $\$ 1.50$ per dozen.

423 INCA-Of taller, stronger growth and more brilliant coloring than Pfauenauge. Standards clear, deep saffron-yellow. Falls velvety dark plum, edged gold in medial line and reticulations at the base. One of the most brilliant varieties.

50 cents each.

42477 INGEBORG-Color effect a white self. This is an intermediate variety of vigorous habit, large flowers and persistent green foliage. (Sand.)

25 cents each.

425 JAPANESQUE-Color effect a light lavender, deep violet bicolor. The standards are reflexed and the falls are spreading, so that the form of the expanded bloom is flat, like that of the double Japanese varieties. Its irregular markings and widespread segments are distinctive. (Sand.)

75 cents each.

473 JAVA-Color effect a yellow and brown. Moderate height. 25 cents each.

474 JEAN CHEVREAU-Large flowers of great texture. S. cream tinted buff yellow; F. milky white stippled at the throat and around all the divisions with brown-violet dotting. A very beautiful flower. (Quality Gardens.) $\$ 2.00$ each.

475 JUBILEE-Buff, heavily spotted dark copper. Large flower, free bloomer and the one distinct advance lately, in this class. The general color effect is a rather dark, rich luscious peach color. (Quality Gardens.)

$\$ 5.00$ each.

42783 LA NEIGE-Color effect a clear white self. This variety is the best white for form and substance yet produced. (Sand.) 35 cents each.

47690 LENT A. WILLIAMSON-Color effect a lavender-violet, velvety royal purple bicolor, reined. This sort is strong in growth and vigorous in production; it has broad, stiff foliage, and heavy stalks and flowers. Its large flowers are noteworthy. (Sand.)

75 cents each. 
47791 LEVERRIER-An enormous flower on $4 \mathrm{ft}$. stems. The color is a combination of Chinese and pansy violet, heavily veined reddish brown on the white throat. The general effect is light red. This is one of the most magnificent irises in existence. (Quality Gardens.) $\$ 2.00$ each.

45382 LOHENGRIN-Uniform soft shade of cattleya-rose. Very large. One of the best of its color.

25 cents each.

42891 LORD OF JUNE-Color effect a light chicory-blue, lavender-violet bicolor. The standards are very large, and inclined to fade and become floppy in intense sun. The tall stalk branches low and widely, bearing its large, oblong flowers well. Its fruity fragrance is an added attraction in the cut flower. (Sand.)

50 cents each.

45479 LORELEY - Color effect a flecked yellow, velvety pansy violet veined bicolor. The flowers are borne on widely branched stalks, and the segments of the blooms expand so that the general effect is that of a short, open bloom with cup-formed standards. Under some circumstances, fall blooms appear. Their bright colors make interesting masses in the border. (Sand.) 25 cents each.

42974 MADAME CHEREAU-Color effect a lavender-white plicata. The flowering stalks are tall and well-branched, and carry the smallish blooms well above the compact foliage. The delicate coloring, the clear penciling, and the symmetrical form of the individual bloom hare not been rivalled by the productions of the modern hybridist. This is one of the best ten, and absolutely lovely, despite its low rating of 74 . (Sand.)

25 cents each. $\$ 2.00$ per dozen.

43085 MADAME CHOBAUT-Standards white shot with pale chalcedony yellow, shading into wine red. Falls white edged with lilac. Very pretty and unique.

75 cents each.

43191 MAGNIFICA-Standards light violet-blue. Falls dark reddish violet, with brown stripes at the base. Very large, sweetly-scented blooms. A striking Iris. $\$ 1.00$ each.

455 MILDRED PRESBY - Standards white. Falls rich dark velvety pansyviolet, with narrow edge of lavender-white. An exceedingly splendid variety for garden use. Its bright shades fill the corner with light and color.

$\$ 1.50$ each.

432 MONS. OLIVER PERTHUIS-A large flowered plant. Stems $4 \frac{1}{2}$ feet or more. Standards blue, shaded mauve. Falls bright purplish violet. Beautiful. $\$ 2.50$ each.

43482 MOUNT PENN-Standards lavender-rose. Falls crimson-lilac. Tall. 35 cents each.

43368 MRS. H. DARWIN-Color effect a white self, veined purple. Its flower stalks are of medium height, well-branched, and freely produced. The individual blooms are compact, well-rounded, and fragrant. It is an excellent white for massing or for cut flowers. Rating too low at 68. (Sand.)

25 cents each.

43564 PALLIDA AUSTRALIS-Color effect a pale blue-violet to pale hortense-violet self. The firm-textured blooms are well rounded, largesized, and fragrant. It is an excellent cut flower. Rating 64 is too low. (Sand.) 25 cents each.

43688 PALLIDA DALMATICA-A pallid violet self. The large blooms ar $\theta$ carried in compact heads well above the foliage. Many strains have been selected from this sort, all having the characteristic cool, lav- 
ender-blue color tones. Its freedom of flowering and its height are its two outstanding characteristics. (Sand.)

25 cents each. $\$ 2.00$ per dozen.

47881 PARC DE NEUILLY-Color effect a deep violet-blue self. This variety is excellent in mass and as a cut flower. (Sand.)

35 cents each.

479 PERLADONNA-The general effect of this flower is very striking, stout branching stems, growing full $3 \frac{1}{2} \mathrm{ft}$. high, bearing many medium-sized flowers of great texture. Color is a pleasing shade of rich "China blue." It was rated 92 by Mr. Wister in 1922. (Quality Gardens.) $\$ 1.50$ each.

43758 PFAUENAUGE-Color effect a bronzed yellow, velvety purple, blended and veined bicolor. The flowering stalks are of merlium height, carrying their interesting, vari-colored flowers in good form. Its fragrance is very good. This variety is interesting in mass. (Sand.)

$$
35 \text { cents each. }
$$

45677 POCAHONTAS-Very large orchid-type flower, with elegantly frilled petals. Standards white, faintly bordered pale blue. Falls pure white.

25 cents each.

43880 POWHATAN--Standards light bishop-violet, with deeper border. Falls deep purple, shaded crimson. Large horizontal spreading flower.

35 cents each.

45775 PRINCESS VICTORIA LOUISE-Color effect a yellow, plum-bordered cream bicolor blend. The plant is vigorous and has well-branched, moderately-tall flowering stalks. Its numerous, good-sized blooms are pleasing in color combination and showy in separate mass planting. (Sand.)

25 cents each.

440 PUMILA EXCELSA-Color effect a brilliant yellow self. This excellent dwarf iris is free blooming and good for its bright color mass in early spring. (Sand.)

25 cents each.

439 PUMILA HYBRIDA CYANEA-Color effect a dark violet self. The individual flowers are rather large for so dwarf a plant and are freely produced, giving a dense mass. For a pumila hybrid this sort holds its color effect longer than usual. (Sand.)

25 cents each.

44184 QUAKER LADY-Color effect a smoky lavender, ageratum-blue, bronzed and blended bicolor. The flowering stalks are freely produced, above medium height, well-branched, and carry their numerous blooms in a fine mass. The soft, smoky lavender, blending with old gold in the fair-sized, firm-textured flowers, is very pleasing when used in mass with bright yellows. This variety is a late bloomer. (Sand.)

25 cents each.

44274 QUEEN OF MAY-Color effect a reddish phlox purple reined self. The moderately-tall, high-branched, flowering stalks are freely produced and well furnished with good-sized, sweet-scented blooms. This is an older sort, outstanding for its pink color mass. (Sand.) 25 cents each.

480 ROBERT BURNS-General color effect purple. Good substance. 25 cents each.

44369 ROSE UNIQUE-Color effect a rose-purple veined self. The stalks are erect, intermediate in height, and well furnished with bloom. The good color mass and the early blooms make th.s var.ety worthy of its place among the intermediates. (Sand.)

25 cents each. 
406 SAMBUCINA-Color effect a pale purplish drab and Chinese violet blended and veined bicolor. The erect flowering stalks are freely produced, and are well and high-branched. The fair-sized flowers are firm in texture and heavily elder-seented. The numerous early blooms are of sombre shade and interesting in mass or as cut flowers. (Sand.)

25 each. $\$ 1.50$ per dozen.

44483 SEMINOLE-Standards dark violet rose. Falls rich velvety crimson. One of the very finest red varieties in existence. Rich in color, not dingy. Wonderful mass effects. Blooms early, with Cecile Minturn, and is an excellent companion in massing. 75 cents each.

40376 SHERWIN WRIGHT--Golden yellow. Vigorous. 2 feet.

25 cents each. $\$ 1.50$ per dozen.

481 SHREVEI- "This is one of Dr. Small's new Irises from the Mississippi valley, which I formerly listed as I. 'versicolor'. It varies much but I offer the identical lavender-blue type which I sent Dr. Small. Unlike most beardless Iris this will thrive in limestone soil even if dry, but it prefers moist places." (Shreve.)

$\$ 2.00$ each.

482 SIBIRICA ORIENTALIS-The Siberian irises have a distinet place in gardening. Their grass-like leaves and small slender flowers give them a characteristic position. They come later than the German irises and are good for entting.

The straight orientalis is a brilliant blue color with the spathe of a erimson shade.
25 cents each.

SIBIRICA-EMPEROR-Large flowers of very fine form and of a deep violet color, borne on stalks 4 feet tall. One of the largest of the Siberian Irises. (Farr.) $\$ 1.00$ each.

SIBIRICA-SNOW QUEEN-Large, ivory-white flowers. Found in Japan by Mr. Barr. (Farr.) 25 eents each.

SIBIRICA-PERRY'S BLUE-A large flower of elear blue with horizontal falls. Probably the finest Siberian Iris. (Farr.) $\$ 1.00$ each.

44583 SINDJKHAT-Color effect a blended lilac-drab, neutral violet bicolor. The flowering stalks erect, stout, exceptionally tall, and well-branched. The blooms are large, open, and of firm texture. (Sand.) 50 cents each.

44693 SOUV. DE MME. GAUDICHAU-Color effect a violet, brilliant blackpurple bicolor. The growth of this variety is rampant, the stalks are tall and well-branched, and the blooms are of extra size, substance, and brilliancy. It is a striking and remarkably early sort. (Sand.)
$\$ 1.50$ each.

SUNSET-The standards are real old gold, finely arehed and of good substance; the falls are copper yellow, with violet and brown. It is a fascinating mixture of real pastel shades. A fine, strong grower, exceedingly free flowering, 3 to $3 \frac{1}{2}$ feet tall. (Quality Gardens.) $\$ 1.50$ each.

48765 VICTORINE-Color effect a white-flecked, brilliant purple bicolor. This plant is interesting for its distinct markings and its graceful stems. (Sand.)

50 cents each.

488 WALNERIANA-An interesting combination of blue and gold. Short. 25 cents each.

44773 WALHALLA-Standards lavender. Falls wine-red. An intermediate. 25 cents each. 
Cat.

No.

48983 WHITE KNIGHT-Color effect a clear white self. The blooms are freely produced and have long, broadly-waved standards and falls which flare to the end of the beard and then droop. The odor is very strongly scented iris. This makes a good cut flower. (Sand.) 50 cents each.

45972 WYOMISSING-Color effect a light pink veined self. Its flowering stalks are freely produced, erect and well and short-branched. The delicately-colored, open blooms are of fair size, frail to firm texture, and delicate color. (Sand.)

ZILIA-Large flowers. S. and F. a uniform shade of dark lavender blue, overlaid rose. Lovely. (Quality Gardens.)

$\$ 2.00$ each. 


\section{Perennial Plants}

Our aim, as stated before, is to acquire one of the most unique stocks of perennials in this part of the countre. We do not carry a large quantity of any kind, preferring to specialize on a wide assortment and on those kinds that are more rare. Mans of our seeds are procured abroad. We are importing plants from our own Southwest, endearoring constantly to find new and beautiful forms fitted to our climate. In alpine and rockery plants we have a special interest.

This sear we are importing the plants of certain species from Europe and hope to list them within a few rears.

Our perennials are listed technicalls according to "Standardized Plant Names". Howerer, we hare used rarietal names from Bailer's Standard Crelopedia of Horticulture, where such names were the onls technical names arailable. Technical names in brackets are not recognized as exact by either of the abore publications.

Unless otherwise noted, $\$ 2.50$ per dozen. This, of course, refers to young plants or dirisions of older ones where division is practicable. If you are interested in larger plants me will quote prices on same if we hare them in stock.

All prices subject to change without notice.

In the spring and earls summer we will hare rarious perennials to offer in two other stages, namels, "Seedlings" and "Transplants". "Seedlings" are tiny plants taken from the original box in which the seed were planted. The price of these is ordinarily $\$ 2.00$ per hundred, postpaid east of the Mississippi Rirer. No less than 50 of a kind can be sold at this price.

"Transplants" are plants that have been once transplanted into other boxes. They have not been planted out-of-doors. They are, of course, much sturdier, stronger plants than the seedlings. It is from this stage that they go into our perennial gardens. The price of a transplant is half that of the field plant so that rery often a considerable saring is possible for those who take adrantage of such an offer.

Adrertisements of Seedlings and Transplants will appear in the magazine

"Horticulture". Please look for them there.

Keep this price-list for readr reference.

630 ACANTHUS mollis (Bear's Breech) - A purple spiked perennial fitted for the back of the border and for sub-tropical effects. Foliage glossy. 3-4 ft. (35 cents each.)

631 ACHILLEA filipendulina (Golden Yarrow)_-"The Achilleas hare proren themselres some of the most desirable plants for the garden, mainly because of their exceedingly free, ret graceful habits of growth." (Hottes.) This is a rellow flowered rariets, growing 4 to $5 \mathrm{ft}$.

100 - ptarmica, Boule de Neige (Double White)-Flowers borne in heads. Centers of the flowers are fuller than those of the Pearl, making it appear of a purer color. 2 feet. Good for a cut flower.

632 - tomentosa (Wooly Milfoil)-A rellow rariets, growing but a foot high.

633 ACONITUM fischeri wilsoni (Wilson's Monkshood)-The Aconitums are suited for woodlands, places under trees, and semi-wild gardens. Flowers are showy and of various colors. This rariety grows 6 feet, blooming in September with pale blue flowers. ( $\$ 5.00$ per dozen.)

635 ADONIS amurensis fi. pl. (Birdseye)- "It is difficult to find a bright flowered plant which blooms as early as does the Adonis. The flowers are a bright and deep rellow, resembling large Buttercups with finels cut, rather ornamental foliage." (Hottes.) This rariety blooms in April. About 1 foot. Rock garden and border plants. (\$5.00 per dozen.)

905 AJUGA generensis (Geneva Bugle)-A superior carpet or edging plant, especially in the shade. Recommended for rockeries, but we onls adrise it in rockeries of considerable size as it is a rery rigorous plant. Blue flowers.

772 ALTHAEA rosea, h. v. Allegheny (Hollyhocks)-This is a new strain of enormous fringed single and semi-double flowers.

$771-\longrightarrow$, double show, extra choice mixed-( $\$ 3.50$ per dozen.)

$55-\ldots$, single mixed. 
ALYSSUM-"Are indispensable plants for the rock garden, especially where plants are needed to droop over the rocks. They are planted along sidewalks, in hanging baskets, and as groups or edges for the border." (Hottes.)

637 - argenteum-Silvery foliage, with yellow flowers. Blooms all summer.

101 - saxatile compactum (Dwarf Goldentuft)-Fine for rock gardens, especially for drooping over rocks. Blooms in early spring.

$636--\frac{h}{h}$. v. luteum-Pale yellow flowers. ( $\$ 3.00$ per dozen.)

10 ANCHUSA italica (Italian Bugloss), h. v. Dropmore-Dropmore variety. A strong-growing, blue-flowered plant. Suitable for heavy backgrounds. Flowers during May and June. 3 to 5 feet. ( $\$ 3.00$ per dozen.)

638 [ANDROSACE lanuginosa] (Rock Jasmine)-A trailer with silvery leaves. Rose-colored flowers in clusters. (\$3.50 per dozen.)

640 ANEMONE hupehensis-" "A new species from central China resembling. a miniature Anemone japonica in growth, with pale mauve-colored flowers which appear in early August and continue to late fall. 1 foot." (Bobbink \& Atkins.)

641 - japonica rosea superba-Single flowers of a silvery rose. Free bloomer. 103 ANTHEMIS tinctoria (Yellow Camomile)-A sturdy, bushy plant with fine-cut foliage. The daisy-like yellow flowers are borne abundantly from June until fall. Succeeds in very poor soil. A very rank grower.

104 - h. v. kelwayi-The best one for gardens on account of its particularly long flowering season. Yellow flowers.

642 ANTIRRHINUM [gibraltaricum]-An uncommon and easily grown species. (\$5.00 per dozen.)

643 AQUILEGIA caerulea [cuprea, Copper Queen] (Rocky Mountain Columbine)-Very few plants of this variety in stock. (35 cents each.)

647 - - hybrida, Dreers long-spurred, mixed-The source of these seed give promise of a rare treat.

648 - _ - Rainbow mixture - A particularly beautiful selection of the long-spurred hybrids from an English source. ( $\$ 3.00$ per dozen.)

645 - canadensis [nana]-This is a dwarf variety of the common native species. Good for rockeries. Orange-red. 9 inches. ( $\$ 3.00$ per dozen.)

650 - flabellata-Dwarf habit with pure white flowers. Early.

651 - formosa truncata [hybrida]-A fine plant; red spurs, yellow mouth. ( $\$ 3.00$ per dozen.)

105 - Mrs. Scott hybrids-A very fine strain.

106 ARABIS alpina (Alpine Rockeress)-Blooms soon after the snow disappears. Small, white flowers with four petals. It makes a very showy mass in the rock garden or border.

652 - [rosea of Thompson and Morgan]-Very dwarf type with abundance of rose-colored flowers. (50 cents each.)

654 ARENARIA montana (Mountain Sandwort)-A charming rock plant, with large white flowers in April and May. ( $\$ 3.00$ per dozen.)

655 - verna [h. v. caespitosa] (Moss Sandwort)-Makes dense moss-like masses. White flowers all summer. ( $\$ 3.00$ per dozen.)

ARMERIA-see Statice.

656 ASCLEPIAS tuberosa (Butterfly Weed)-A very showy orange milkweed. July and August.

657 ASCLEPIODORA decumbens (Antelope Horns)-Introduced from the Southwest. "Many spreading, narrow-leaved stems, each ending with a large hemispherical head of geometrically-perfect, sweet-scented, greenish-cream flowers with purple hoods." (Bridwell Bros.) (50 cents each.)

ASTER-Without doubt one of the most satisfactory fall flowers we can grow in our climate.

658 - alpinus (Blue Mountain Daisy)-Contrary to the general rule, this aster blooms in May and June. Excellent for the rockery. (25 cents each.)

659 - - albus magnificus-White flowers. Early. (25 cents each.)

109 - amellus, Iutetia major-Large flowers. A nice light lavender-violet. August and September, 18 to 24 inches. ( $\$ 3.50$ per dozen.)

662 - novae-angliae (New England Aster)-Showy purple wild species. 3 to $5 \mathrm{ft}$. September to October. (25 cents each.) 
Cat.

No.

$663-\longrightarrow$, Lil Fardel-Large, rich, elear pink. 4 to $5 \mathrm{ft}$. August to September. (25 cents each.)

$664-\longrightarrow$, Mrs. F. W. Raynor-Large purplish-crimson. $4 \mathrm{ft}$. (25 cents each.)

665 - - roseus-Bright purplish-mauve. $4 \mathrm{ft}$. (25 cents each.)

666 - - Ryecroft Pink-Bright rosy pink. 4 to $5 \mathrm{ft}$. September to October.

667 - novibelgi, Climax-One of the best. Very showy with its large larenderblue blooms. 5 feet. (25 cents each.)

$668-\longrightarrow$, King of the Belgians-Large lavender-blue, semi-double. 5 feet. September to October. (25 cents each.)

$670--$, Robinson, V. C.-Maure. Double flowers. 4 to $5 \mathrm{ft}$. September to October. (25 cents each.)

111 - - St. Egwin-We find this an extremely raluable variety. Very dense, bush-like plant with pink blooms. 3 feet. September to October.

671 - - White Climax -4 to 5 feet. August to October. (25 cents each.)

112 - subcaeruleus (India Aster)-Dense tuft of leares. Leafless stems 12 inches high. Very large bluish-violet flowers in June and July.

672 - tataricus-A very late aster, its bluish-violet flowers not coming till October and Norember. 5 to 6 feet.

- miscellaneous varieties.

673 - No. 3-An aster from the Southwest, name unknown to the firm sending it to us. Very dwarf with good-sized violet-blue blossoms. Dry rockeries. Late summer to freezing weather. (35 cents each.)

$674-\longrightarrow$, Brussells-Very large, light, larender-blue. $4 \mathrm{ft}$. (25 cents each.)

675 - C Capitaine-light lavender-blue. 4 to $4 \frac{1}{2}$ feet. ( 25 cents each.)

676 - C Chaterham Gem-(25 cents each.)

677 - - Emilie Thoury-Light ageratum-blue. 3 feet. (25 cents each.)

678 - - Enfant Devitry-Semi-double lilac-mauve. $2 \frac{1}{2}$ feet. (25 cents each.)

679 - - Ghent-Large, soft lilac-mauve. 3 feet. (25 cents each.)

$681-\longrightarrow$ Grey Lady-(25 cents each).

110 - - mauve cushion-The Japanese hardy aster. Makes a circular cushion-like plant 30 inches across, 9 inches high. Flowers mauve, with silvery white reflection, measuring over $11 / 4$ inches in diameter. Blooms begin to unfold in early October. ( $\$ 3.50$ per dozen.)

683 - Mrs. C. L. Hutchison--(25 cents each).

684 - - October Dawn-Lilac-maure blooms. 2 feet. (25 cents each.)

686 - - President-Large light bluish-violet. 4 feet. (25 cents each.)

687 - - Royal Blue-A very fine rariety with us. (25 cents each.)

688 - - Sam Banham-Large feathery pure white. Early. 3 feet. (25 cents each.)

689 - - The Queen-(25 cents each.) 691 - - each.) Trouvaille--Semi-double bright maure-pink. 3 feet. (25 cents

113 ASTILBE, mixed-Many branched feathered heads of flowers during June and July. ( $\$ 4.00$ per dozen.)

694 AUBRIETIA deltoidea graeca (False Wall Cress)—“Few persons have grown the Aubrietias because they have not known of them. They are useful in the front line of a perennial border or for the rock garden." (Hottes.) This particular variety has large violet flowers. ( $\$ 3.50$ per dozen.)

695 - hendersoni-An excellent variety with very large rich purple flowers. ( $\$ 3.50$ per dozen.)

696 - leichtlini - Another excellent variety with large rosy-carmine flowers. ( $\$ 4.00$ per dozen.)

697 - [hybrida grandiflora] finest mixed-New large flowering rarieties. In many shades. (\$3.00 per dozen.)

698 - [Mrs. Lloyd Edwards]--Beautiful crimson-purple flowers. (40 cents each.) 
114 BAPTISIA australis (Blue Wild-Indigo)---Strong growers, flowers on 6-inch spikes. 3 feet high. Dark blue. Blooms in June.

700 BolToNiA asteroides (False Chamomile)-A fire to seren-foot plant bearing thousands of aster-like flowers. Very desirable in the back of large perennial borders. August-October.

701 - latisquama nana-A Boltonia only two feet tall! Pinkish-lavender flowers. Very desirable. August-September.

702 BUPHTHALMUM salicifolium-A composite with yellow flowers. A neat border plant growing 2 feet. ( $\$ 3.50$ per dozen.)

116 - speciosum-A showy Hungarian species, bold foliage, yellow flowers. 5 feet. (\$3.50.)

T03 CALAMINTHA alpina-A very pretty dwarf plant, purple flowers. 6 inches. June.

704 CALIMERIS incisa-Very much worth while. Looks like an aster but begins to bloom in July, continuing through August. Light blue. 2 feet.

706 CALLIRHOE involucrata (Poppy Mallow)-Long, trailing stems. Flowers saucer-shaped and a showy crimson.

707 CALOPHANES linearis (Polkadots)-Introduced from the Southwest. "A low herb with many erect, leafy branches, up to a foot high, bearing a constant succession of wide-mouth, riolet-blue flowers with purple dots in the throats. Spring and summer." (Bridwell Bros.) (50 cents each.)

CAMPANULA-"There is hardly a group of flowers which possesses such rare beauty as does the large genus of Campanulas. All of them are desirable and seem to just fit in their various places from the formal border to the rocky ledges of the woods. Most of them bloom during June and July." (Hottes.)

708 - [elegans]-Lilac flowers of excellent form. For borders and rockeries. $1 \frac{1}{2}$ feet. All summer.

709 - glomerata dahurica-Tery showy, rich, deep, violet flowers in large heads. $1 \frac{1}{2}$ feet. (50 cents each.)

117 - grosseki (Grossek Bellflower)-Neat, bell-shaped, violet flowers in long racemes all summer. 2 feet. ( $\$ 3.00$ per dozen.)

711 - lactiflora-Large heads of milk-white, blue flowers. 3-4 feet.

712 - alba-Creamy white. 5 feet. July to August.

36 - medium, double mixed (Canterbury Bells)-An excellent biennial.

$710-\longrightarrow$, single mixed.

37 - calycanthema (Cup-and-Saucer Bellflower)-An interesting variety.

118 - persicifolia, named varieties, mixed, from English seed (Peach Bells)Narrow leaves. Very showy. Up to 5 feet. (\$4.00.)

125 - pyramidalis (Chimney Bellflower)-A rery conspicuous bellflower. 4 to 6 feet. Large silver-like porcelain-blue flowers in August.

126 CENTAUREA dealbata (Persian Centaurea)-Distinct bright rose-colored flowers. July-September. $1 \frac{1}{2}$ feet.

127 - macrocephala (Globe Centaurea)-Perhaps the showiest of the perennial centaureas. The yellow thistlelike flowers are very large. Plant erect, somewhat spindly, stiff stems.

715 - montana (Perennial Cornflower)-Deep blue. 11/2 feet. June to Sept.

716 CENTRANTHUS ruber (Red Valerian)—Red flowers, sweet scented. JuneJuly.

128 CERASTIUM tomentosum (Snow-in-Summer)-Low-growing, with silvery foliage. White flowers in June. Invaluable for the rockery and as an edging plant. Fine as a covering for graves or steep bank. Any soil.

129 CHELONE lyoni (Pink Turtlehead)-A late summer plant, beginning to blossom about the midale of August. About 3 feet tall with rose-purple flowers. Flowers are inflated and long tube-shaped, somewhat like Snapdragon. 
719 CHRYSANTHEMUM arcticum (Arctic Daisy)-One of the best fall perennials. White flowers somewhat tinged rose or lilac, 2 inches across. 1 to $1 \frac{1}{2}$ feet. September-November.

69 - coccineum (Pyrethrum or Painted Lady)-Main crop in June, but if they are not allowed to go to seed, will bloom more through the summer and autumn. The fernlike foliage is rery attractive. Our stock is ordinarily sold under the name Pyrethrum hybridum.

130 - coreanum (Korean Chrysanthemum)-With us we find the location of this plant has a great deal to do with its success. A sheltered southerly exposure, somewhat shady, gare fine results. The foliage is much more attractive than that of the ordinary hardy chrysanthemums, being a bright glossy green. The flowers are single, of a light flush pink.

131 - hortorum, Japanese hybrids-This last year was the first we had tried this group. Late as the season was they did not bloom outside although some of them flowered later on in one of the greenhouses. Their ralue to us is as yet uncertain.

42 - - mixed varieties-This is the common chrysanthemum. They should be planted in a southern exposure where there is protection against the northwest winds. (\$2.00.)

132 - maximum, h. v. Shasta Daisy-A well-known free-flowering summer daisy. White.

718 - - h. r. - Burbank hybrids-( $\$ 3.50$ per dozen.)

720 CONVALLARIA majalis (Lily-of-the-Valley)-Plant in shady spots.

43 COREOPSIS lanceolata (Lance Coreopsis)-A profusely flowering plant for the hardy border. Blooms continuously and is good as a cut flower. Yellow.

133 - - h. v. grandiflora fl. pl.--We do not call this a true double, but it is a good heary single and semi-double. (\$2.75.)

723 - rosea-A nice little plant. About $1 \mathrm{ft}$. Rosy-pink flowers and fine leaves.

724 COTYLEDON [simplicifolia]-A beautiful species with deep rellow flowers in racemes. 6 inches. (50 cents each.)

725 CRUCIANELLA stylosa (Crosswort)-Pink flowers in large heads. A pretty trailer for dry banks or rocks. June-September.

DELPHINIUM-One of the best groups of plants arailable. It is hard, if not impossible, to find anyone who does not admire their beautiful shades and stately growth.

45 - formosum (Hardy larkspur)-Dark blue with white center, in close spikes.

134 - grandiflorum chinense (Slender Larkspur)-Finely divided leares. Short stems. Gentian-blue or white (alba).

44 -h.v. Belladonna-Turquoise blue. This plant needs no introduction. An old favorite. Do not allow it to go to seed and you will have flowers until frost.

135 - h.v. Sir D. Haig-The flowers are rery large, color deep purple and blue, while the spike is enormous. ( $\$ 3.00$ per dozen.)

90 - Vanderbilt strain-A wonderful collection of shades and forms. No one will make any mistake in buying these beautiful hybrids to beautify his home. (\$4.00.)

729 - Wetterlow's strain-A very fine assortment. (\$3.00.)

DIANTHUS (Pinks)--We have a natural tendency to grow a great many of the rarious pinks as our first venture was indoor carnations. They are still numbered among the old-fashioned farorites.

136 -. [allwoodii]-A new hybrid race, Perpetual Flowering Carnations X Hardy Garden Pinks. The form, perfume and beauty of the old-world Garden Pink blended with the perpetual flowering qualities of the modern greenhouse Carnation. (\$3.00.)

137 - [allwoodii alpinus]- "A new break in the Allwoodii section. It is a short, compact-growing plant (about $T$ inches) and has been specially developed for growing in walls, rockeries, crazy paths, etc. At present colors are restricted to whites, pinks and rose pinks." (\$4.00.)

730 - [arenarius]-Flowers pale purple, fringed. A good rock plant. 5-8 in. July-September. (\$3.00.) 
- caesius (Cheddar Pink)-Pretty bright pink flowers, a lovely plant for the rock garden, dry banks and similar situations.

732 - chinensis (China Pink) - Nice fringed flowers in various shades. Last till frost. A biennial.

733 - cruentus-Very dark crimson blooms borne in clusters. Good for the. border. 1-2 ft, July. (\$2.75.)

734 - delicata-This is a fine type of Dianthus. Single rose-pink, petals striped red.

735 - deltoides (Maiden Pink)-A dwarf trailer. Pink. Excellent for the. rockery. 8 inches. June-August.

$736-$ [albus]-White form.

47 - [dentosus]-Probably not a distinct species, though so rated by Thompson and Morgan of England. A beautiful old kind; large dark purple. flowers.

737 - glacialis neglectus (Glacier Pink)-Alpine species, flowers bright rosypurple. (\$5.00.)

138 - [Hardy Perpetual Border]-“"A hybrid race-Borders X Perpetual Flowering Carnations, possessed of the form, beauty and hardiness of the Border Carnation, with the freedom of flowering of the Perpetual Flowering Carnation." (\$3.00.)

78 - latifolius, single and double mixed. (Double Cluster Pink)-Good for summer bedding work. A continuous bloomer. Mostly double pinks. and reds.

139 - [atrococcineus] (Everblooming Sweet William)-Different shades of red. 18 inches. Continuously blooming in summer.

79 - plumarus, mixed (Grass Pink, also called Garden Pink)--Very fragrant, with fringed or jagged petals. Colors vary from white to bright scarlet, and are very dainty.

739 - superbus-Flowers soft lavender, fringed; very fragrant. $1-1 \frac{1}{2} \mathrm{ft}$. June-August. (25 cents each.)

740 DICENTRA spectabilis (Bleeding-Heart)-An old-time border plant and one of the prettiest. 11/2 feet. April-June. (\$5.00.)

741 DICTAMNUS albus (Gas Plant)-Extremely desirable. It takes a number of years to form a good-sized clump but is well worth it. It has large trusses of white flowers that are excellent for cutting. Suitable as a border or specimen plant. (\$5.00.)

140 DIGITALIS purpurea, The Shirley--This is a strain of the Gloxinia-flowered type, and is a magnificent race. (\$3.00.)

743 DORONICUM caucasicum (Leopard's Bane) - A large yellow daisy-like. bloom in May and June. $12-18$ inches. Very good. (35 cents each.)

744 - plantagineum excelsum-Here is a wonderful variety with blossoms 4. inches across. Begins to bloom in early spring and continues through the summer. Excellent for cutting. Splendid for the border. (\$3.50.)

83 ECHINACEA purpurea (Giant Purple Cone-Flower)-Flowers about 4 inches across; peculiar reddish-purple with a large brown cone. July to October. 3 feet.

745 EPIMEDIUM [bicolorum] (Barrenwort)-Of the Barrenworts as a whole. Hottes writes: "If they are picked close to the ground when the leaves. are mature, they will last at least two months in water. They are good for pot plants and for the border where they should really be planted in masses in order that their delicate flowers may be appreciated. They are. excellent plants for the rockery." May-June. 9 inches. This variety. is rosy brown. ( $\$ 3.50$.)

746 - macranthum-Cream-white, waxy. 5-10 inches. April-May. (\$3.50.)

747 - niveum-Snow-white. April-July. (\$3.50.)

748 - [sulphureum]-Pale yellow. Dwarf. April-July. (\$3.50.)

81 ERYNGIUM planum (Sea Holly)--Steel blue. 2 feet. Useful for cut flowers or to dry for winter. (\$3.50.)

142 EUPATORIUM aromaticum melissoides (Melissa Thoroughwort)-Some-times called E. fraseri. White, fine for cut bloom. 
143 - coelestinum (Mist-flower)-Mrriads of small, fluffr, azure-blue flowers. Blooms in August and September. 2 feet.

144 - urticaefolium (Snow-Thoroughwort)-Sometimes called E. ageratoides. Pure white flowers. \pm to 5 feet tall.

49 GAILLARDIA aristata (Common Perennial Gaillardia or Blanket Flower) -Sometimes called G. grandiflora. A well-known showy plant.

$145--$ Copper Red-Te have found out that this raries from seed considerably. Howerer, we have secured cuttings from one or two of the best plants. These are of a rery cxcellent color.

$1 \pm 6$

- - Golden Gleam-(35 cents each.)

750

- - Ipswich Beauty-Descritied in an English catalogue as the largest and best-colored rariety. (\$5.00.)

751

913

- - Portola_Petals a good red, just tipped with rellow.

$(\$ 5.00$.

753

147

GALIUM boreale (Northern Bedstraw)-Fine white flowers.

GENTIANA tibetica-Creams white. Creeping. Mar. (\$5.00.)

GEUM chiloense (Chiloe Avens) [atrosangineum fl. pl.]-Brilliant scarlet double flowers. Mas to October. 15 to 15 inches. (\$3.00.)

$75 \pm$

148 part of summer and fall. 2 feet. (\$3.50.)

- Mrs. W. J. Bradshaw-Very large tlowers, $11_{12}^{1 / 2}$ to 3 inches across. Petals bright crimson. Good for borders and rockeries. (\$3.00.)

- [Orange Queen]-An orange companion for Mrs. Bradshaw. ( $\$ 3.50$.)

- [sibiricum]-Large coppers-scarlet flowers. A beautiful species. 12-15 inches. Mas-June. (50 cents each.)

GYPSOPHILA paniculata (Baby's Breath)-Forming a film of white, it should be planted amongst other flowers. A nice cut flomer to lighten up all sorts of floral arrangements. Ters large plants. ( 75 cents each.)

fl. pl.-Double. These are rers fine grafted stock, good-sized plants. ( .5 cents each.) Then we also hare small plants from seed for fall delivery. Of course, not all these will come double. (\$2.50.)

- - Bristol Fairy-A beautiful rariety. (\$1.00 each.)

759

760

- - Ehrlei-Another very fine strain. (\$1.00 each.)

HELENIUM autumnale (Sneezeweed)-Ters useful in the large border for fall effects. Excellent for planting among shrubbers. This rariets is rellow.

- - - rubrum-Terra-cotta or mahoganr-crimson. 5 feet. (\$3.00.)

HELIANTHEMUM [multiflora] (Sunrose)-Pink-salmon flowers. Ters attractire. I fine plant for the rockerr. (\$3.50.)

HELIOPSIS (Orange Sunflower)-Good for eutting both as to length of stem and lasting qualities. Borders or dry situations.

150 - helianthoides pitcheriana-Single flowers of a deep golden rellow. 2-3 feet. Juls-September.

151 - scabra zinniaeflora-Flower large deep yellow and rers shows, free and continuous bloomer. (\$3.00.)

HEMEROCALLIS (Day Lily) - A group of rers desirable plants. Bloom freels. Cseful for naturalizing. Good in the border or amongst shrubbers.

- aurantiaca (Orange Day L.) - Very large deep orange flowers, shaded brown. Juls. 2 feet.

- citrina-Pale lemon-rellow flowers and a tall grower. June-July. - dumortieri-Bronze vellow on outside and a rich sellow within. 2 feet.

- flara (Lemon Day L.) - Sweet-scented, clear yellow flowers. 3 feet. June. rellow large flowers. 201/2 feet. Juls.

- middendorff-Rich golden-rellow flowers. 2-3 feet. June-July.

- hort. var. Apricot-Apricot-rellow. $2 \frac{1}{2}$ feet. June.

770 Aureole-Deep sellow. 21/2 feet. June.

- D Dr. Regel-Dark rellow. 2 feet. June-Juls.

- Gold Dust-Orange. 3 feet. June.

Sir Michael Foster-Very fine. ( 75 cents each.)

Sorereign-Dark orange. 2-3 feet. June-Juls. 
773 HESPERIS matronalis (Sweet Rocket)-Well-known, old-fashioned flower. For use in the border.

159 - nivea-"A very rare Dame's Violet known to botanists for some time but which has just recently been introduced to cultivation. Pure white flowers during May and June. The racemes, when fully expanded, are about 1 foot long. The flowers are very sweet-scented. It is a handsome new perennial for the herbaceous border; height 2 feet." (35 cents each.)

774 HEUCHERA sanguinea, Flambeau (Coral Bells)-.-The evergreen leaves resemble geranium leaves. The delicate flowers are borne on a graceful stalk. This new variety has reddish flowers and is excellent for rockery and shrubbery work. (\$5.00.)

- splendens-More of a coral pink color. (30 cents each.)

HIBISCUS moscheutos, giant hybrid mixed (Marsh Mallow)-These tropical appearing plants have a range of color from white to crimson. Flowers several inches across. Too large for the ordinary garden border.

HOLLYHOCKS--See Althaea.

IBERIS (Candytuft)-Foliage evergreen. Excellent for use in rock gardens, beds, and for covering bare spots. They form dense mats.

778 - gibraltarica-The largest Candytuft but somewhat straggly. White flowers deeply tinted rose-lavender. 1 foot. May-June.

779 - sempervirens-Pure white. 10 inches. April-June. (25 cents each.)

780 - h. v. Little Gem-White. Compact. 6 inches. April. ( $\$ 3.50$.)

781 INCARVILLEA delavayi--Rose-colored flowers in clusters on long stems. Large trumpet-shaped blooms. June. (50 cents each.)

782 INULA glandulosa (Fleabane)-Yellow, small flowers. Very showy. 8 in. July-September.

625 KNIPHOFIA foliosa (Sword Torch Lily) - Strong growing and thick stalked. Blooms late in May with spikes 10 to 12 inches long. Orange-red at first, but yellow on bottom half as bloom matures. We found this variety very hardy with a light covering. (\$3.00.)

625 - uvaria grandis (Red Hot Poker)-Any ordinary garden soil, but responds well to good treatment. Should be given protection, or else stored over in sand in a cool cellar. August to October. Spikes a rich orangescarlet, 3 to 1 feet above the ground. (\$3.00.)

910 LATHYRUS latifolius (Perennial Pea) (h. v. Pink Beauty)-Similar flowers to the Sweet Pea, on many-flowered stems. Very desirable. This variety has deep rose flowers. 3 feet. June-August.

911 - - (h. v. Rose Queen)-Bright pink. 2 feet. June-August.

912 - (h. v. White Pearl)-Pure white. Double the size of ordinary Lathyrus. A beautiful subject. 2-3 feet. June-August. (\$3.50.)

782 LAVANDULA officinalis (Sweet Lavender)-An old-fashioned favorite. Long spikes of blue lavender flowers. Borders, dry banks, rock gardens.

783 LEONTOPODIUM alpinum (Edelweiss)-A very hardy, distinctive plant. 5 inches. June-July. (\$3.50.)

56 LIATRIS pycnestachya (Cattail Gayfeather or Blazing Star)--Large spikes. of light rosy-purple flowers in July and August. 5 feet.

LILY-OF-THE-VALLEY-See Convallaria.

LIMONIUM (Sea Lavender) - A very desirable group. Flowers may be dried as everlastings, and lend the lightness to a bouquet that Baby's Breath does.

788 - gmelini-Violet-blue, large-branched flower clusters. A good border plant. (35 cents each.)

621 - latifolium-Small lavender-blue flowers, in large clusters.

791 - mixed-(35 cents each.)

LUPINUS polyphyllus (Washington Lupine)-Produces large spikes in May and June. Preferably in a semi-shady place. Cut the blooms and prolong the flowering season. 3 feet.

- - albiflorus-White. (\$3.00.)

- - blue- $(\$ 3.00$.)

- Regal Strain, buffs-Novel and beautiful shades of buff, amber, ete. $(\$ 5.00$. $)$ 
Cat.

No.

798 - Regal Strain, yellow shades-These include various shades of yellow, orange, bronze, etc., in bewitching variety. (\$5.00.)

Rose Queen-A beautiful rose-colored variety. $(\$ 5.00$.)

796 - hort. var. Sunshine - The finest deep yellow yet raised. $(\$ 5.00$.

LYCHNIS-For different places in your garden there are many good varieties. All are used for cut flowers, in perennial borders and rock gardens. Period of bloom of the genus extends over the summer months.

800 - alpina-Red-purple; neat plant for the rockery. 6 inches. April.

161 - chalcedonica (Maltese Cross)-Heads of brilliant orange-scarlet in June and July. 2-3 feet.

$60--$ [alba] (London Pride)-White. (\$2.00.)

801 - haageana-Single orange-scarlet flowers of large size. A spectacular flower. 1 foot. May-Jume.

61 - viscaria splendens (German Catchfly)-Spikes of double rose-pink fragrant flowers. There is a curious viscid area on the stem below the flowers.

162 LYSIMACHIA nummularia (Moneywort)-Makes a dense carpet under trees or shrubs where grass will not grow. This makes a fine plant for the winter hanging pot indoors.

163 LYTHRUM salicaria roseum-Large spikes of rose-colored flowers. $3-4 \mathrm{ft}$. July- September.

63 MONADA - hort. hybrids. (Beebalm)-Our stock of these consists of rarious shades of larender. Showy, growing 4 feet high. Any soil. July and August.

802 MYOSOTIS [hybrida, Ruth Fischer]-A first-class forget-me-not. Brilliant light blue, flowers extra large.

804 NIEREMBERGIA rivularis (White-Cup)-A rockery plant, dwarf, creeping, alpine. Large cup-shaped white flowers nestling among the leaves. Very interesting. ( $\$ 3.00$.)

65 OENOTHERA fruticosa youngi. (Young's Sundrops)-Masses of fine yellow. Continuously blooming. Likes moisture. Easily grown. 11/2 feet.

64 - glauca fraseri (Evening Primrose)-Yellow flowers. Good border plant. Good for exposed places in the rockery. 1 to 2 feet.

164 PACHYSANDRA terminalis (Japanese Spurge)-Trailing. 6 to 8 inches high. A fine ground corer either in shade or sun. Glossy foliage. Мay be used in window boxes. (\$2.75.)

PAEONIA-A favorite always. We feel our selection of rarieties will bo very satisfactory. We sell standard dirisions only.

168 - Adolphe Rousseau-Rating 85. Early mid-season. Very tall and strong. Rather loose, sometimes semi-double flowers of deep garnet color. Excellent. ( $\$ 1.50$ each. $\$ 12.00$ per dozen.)

169 - Duchesse de Nemours-Rating 81. Early mid-season. Blossoms cupshaped, wide guard petals white. Narrower middle petals sulphur yellow with often a marking of green. (75 cents each. $\$ 7.50$ per dozen.)

170 - Edulis superba-Rating 76. Tery early. Deep rose-pink with occasional crimson marking. (50 cents each. $\$ 5.00$ per dozen.)

806 - Etta-Rating 80. Exceptionally large, semi-flat blooms of a very fine shade of shell-pink. Very late. (\$1.50 each. $\$ 15.00$ per dozen.)

807 - Eugene Bigot-Rating 83. Tery fine brilliant crimson. Late mid-season. ( $\$ 1.75$ each. $\$ 17.50$ per dozen.)

808 - Eugenie Verdier-Rating 86. A tall free-bloomer. Delicate flesh center with outer petals of a beautiful satiny sheen. Mid-season. ( $\$ 1.50$ each. $\$ 15.00$ per dozen.)

$1 i 1$ - Felix Crousse-Rating 84. Mid-season to late. Compact bloom of large size and good form. Deep ruby red, center somewhat deeper. Choice. (\$1.00 each. $\$ 10.00$ per dozen.)

172 - Festiva maxima-Rating 93. Mid-season. Very large ivory-white. Appearance rather feathery with a crimson fleck in the center. (75 cents each. $\$ 7.50$ per dozen.)

809 - Karl Rosenfield-Rating 88. Brilliant dark crimson. Good form and substance. ( $\$ 1.50$ each. $\$ 15.00$ per dozen.) 
810 - Livingstone-Rating 81. Light silvery pink, often flecked with carmine in center. A free bloomer. Compact flowers. ( $\$ 1.50$ each. $\$ 15.00$ per dozen.)

811 - Loveliness-Rating 88. Light pink blooms tinted lavender. Large, flat, full flowers. Late. ( $\$ 3.00$ each. $\$ 30.00$ per dozen.)

173 - Marguerite Gerard-Rating 84. Late. Globular blooms of flesh-pink fading to creamy white showing a ring of gold when fully dereloped. Strong grower and free bloomer. ( $\$ 1.50$ each. $\$ 12.00$ per dozen.)

174 - Mme. de Verneville-Rating 79. Early to mid-season. White. Center flesh-pink when first opened. Center petals sometimes tipped with carmine. (75 cents each. $\$ 7.50$ per dozen.)

812 - Solange-Rating 97. "Extra large flowers with broad rounded petals of such fine form that the flower does not look coarse. Petals waxy white but suffused with a reddish golden light, so that the total effect is such as may be seen on a cloue at sunset. One of the rery finest. Late mid-season." (Cherry Hill.) (\$3.50 each. \$35.00 per dozen.)

813 - Therese-Rating 98 . "One of the rery best and probably the most satisfactory variety in commerce. Vigorous and free-blooming, producing large flowers of soft shell-pink with lighter center. Stems of medium height and good strength mid-season.” (Cherry Hill.) (\$3.50 each. $\$ 35.00$ per dozen.)

175 - Venus--Rating 83. Mid-season. Pointed buds, opening into large, compact flowers of shell-pink with a flesh-white collar. A rery fine Peony. (\$1.50 each. $\$ 15.00$ per dozen.)

814 PAPAVER nudicaule, h. v. Tangerine-The Iceland Poppies grow about 1 foot in height. Excellent subjects for the border. This particular rariety is a fiery orange, of great size, orer 90 per cent true to color. A fine variety. (\$3.50.)

- orientale-The Oriental Poppies make a gorgeous show in the spring. More and more are they coming into faror, not only the older scarlet shade, but the newer colors also.

815 - Duke of Teck-Light erimson. (\$3.50.)

165 - Edna Perry-Large flowers of a soft salmon pink. Very popular. $(\$ 4.00$.

906 - Grossfurst-Dark red, with black blotehes. (\$3.50.)

816 - Mrs. Perry-Orange-apricot. (\$3.50.)

817 - Perry's White--Purest white. (\$5.00.)

818 - - [Princess Victoria Louise]-Soft salmon-rose, shading to blushrose. $(\$ 3.50$.

166 - Royal Scarlet-Large flowers of brilliant scarlet, with black blotches. (\$3.50.)

819 PARDANTHUS chinensis-Blackberry Lily - Orange blooms, spotted purple-brown. Foliage in spring very similar to the Iris but the leaves follow up the stem to some extent, and the flowers are lily-shaped, 2 inches across. An unusual and showy plant. (\$3.50.)

820 PARONYCHIA [dichotoma]-Described from the Southwest whence we introduced it, as follows: "A rare plant from the highest ranges of the Ozarks which has received high praise in the East as a rock plant or cover. It makes a mat of fine grassy leaves with myriads of yellow flowers in autumn." (Shreve.) (50 cents each.)

PENTSTEMON (Beard Tongue)-Beautiful border plants, but do not do as well in the North. Very showy, with long, slender spikes bearing many trumpet-shaped blooms. June through September. Good for cutting and the border.

821 - barbatus-A beautiful scarlet, up to 3 feet.

167 - torreyi-Foliage light green. Stems wiry and thin. Brilliant scarlet flower spikes. 3-4 feet.

198 PHLOX amoena-Very good as a ground coverer, or as a rockery or border plant. 4 inches. A mass of bright pink in spring. (\$2.75.)

PHLOX [decussata]-The following are horticultural varieties of P. paniculata and P. paniculata X P. maculata. They are ordinarily called P. decussata. 

Africa-Ruby-crimson with darker center. (\$4.00.)

- Albion-Pure white, with a faint red eye.

Baron von Dedem-Salmon red.

181

182

828

183

184

185

186
- B. Comte-Rich satiny amaranth. (\$3.00.)
Beacon-Brilliant cherry-red.

- Bridesmaid-White, crimson center.

- Clara Benz-Brilliant rosy carmine, with white eye and violet halo; medium tall. (\$4.50.) bloom. $\quad(\$ 3.00$.

nder-New. Crimson-red with darker eye. A rery striking

- Commander-in-Chief-Crimson red with darker eye. (50 cents each.)

- Coquelicot-Orange scarlet. (\$3.00.)

- Debs-A fine red Phlox. Bright fiery crimson. (80 cents each.)

- Elizabeth Campbell-One of the best. Bright salmon-pink, with lighter shadings and dark red eye. (\$2.75.) - 3 ft. Evelyn-Rich salmon-rose; flowers large and of perfect form.

187

188

830

- - Fuerbrand-New. Bright rermilion-scarlet. (\$3.50.)

- Graf Zeppelin-White with red eye. (\$4.50.) (\$5.00.)

189

190

191

192

193

194

195

831

196

832

197 - glaberrima suff ruticosa, Miss Lingard-One of the very best. Excellent $(\$ 1.00$.

- Johnson's Favorite-Light salmon-pink with dark red eye. Strong grower. (\$弓̈.00.)

- Le Mahdi-Deep velrety purple. (\$3.00.)

- Mme. Paul Dutrie-Soft pink suffused with white.

- Mrs. Jenkins (Independence)-White. Free bloomer.

Mrs. Scholten-New. Dark salmon-pink flowers in large spikes.

- - Nana coerulea-Lavender blue.

- - Rijnstroom (Rynstrom)-Lorely rose-pink. Large clusters of flowers.

- von Hochberg-Dark crimson. A beauty. (35 cents each.)

- W. C. Egan-Very large flowers of delicate lilac. $(\$ 3.00$.

- divaricata, Lapham, Perry's var.-Large lilac-blue blooms. Excellent for the rockery or border. 1 foot. (50 cents each.) white flowers in June and also in the autumn. Foliage of an excellent habit.

$83 \pm$

- ovata (carolina)--Bright rosy red. 1-11/2 feet. June-July. (30 cents each.)

199 - subulata (Moss Pink)-Foliage evergreen. An early flowering dwarf pink phlox.

835

836

837

838

839

840

841

- C. F. Wilson-Soft larender. Very good. (\$3.50.)

- - lilacina-Light blue.

- nelsoni-Small white blooms.

- newery seedling-Pale maure.

- - Vivid-Bright rose. $(\$ 3.00$.

- white-

PHYSAL1S francheti (Chinese Lanterns)-An interesting plant for its brilliant orange fruits.

6 PHYSOSTEGıA virginiana (False Dragonhead)-Beautiful mid-summer perennial. Forms dense bushes 4 to 6 feet high. Spikes of delicate tubular Howers, bright soft pink.

$89--$ aloa (White False Dragonhead)-Fine rariety.

6i PLATYCODON grandifiorum (balloon Flower)-Closely related to Campanula. Attractive blue flowers. July to October.

68 PuTENTiLLA doubie hybrids, mixed-Charming plants for the border. June to August. Any soil. Fractically all of ours are of a deep red color. $1 / \frac{1}{2}$ teet. (\$3̈.j̄0.)

813 - nepalensis, h. v. Roxana-"A charming new variety of this popular border plant with very large flowers of a brilliant salmon color with darker rems towards the base. The ripe anthers with yellow pollen look like golden ornaments on a relvet cushion." (Thompson \& Morgan, England.) (\$5̄.งU.) 
844 PRIMULA japonica [eximia], splendid mixed-An extra fine strain of this excellent Japanese Primrose. (\$3.50.)

601 RANUNCULUS repens [fl. pl.] (Double Creeping Buttercup)-Masses of yellow flowers in May and June.

83 [Rudbeckia purpurea]-See Echinacea purpurea.

70 - speciosa (newmanni) (Showy Cone flower)-Dark orange-yellow, with deep purple cone. July to September. 3 feet.

602 SALVIA azurea-A large number of pretty sky-blue flowers in August and September. 3 to 4 feet.

847 SANTOLINA chamaecyparissus incana (Lavender Cotton) - A very beautiful foliage plant for the rockery. In rich soil grows to good size.

SAXIFRAGA-Here is an extremely interesting group of plants, especially for those who delight in the rock garden. We have a number of interesting kinds at present and will augment this number with importations from abroad.

848 - [athlete]-One of the finest varieties. (\$5.00.)

603

-.crassifolia (Leather saxifrage)--A rery effective early spring Hower. They will grow almost anywhere. Low-growing, attractive foliage witì flower clusters of rosy-pink flowers about one foot from the ground. $(\$ 3.50$.

849 - [Leichtlini]-Rose-colored flowers. 1-11/2 feet. April-June. (\$5.00.)

850 - [longifolia]-A curious type with lime deposits along the leaf-edges. Large branching clusters of white flowers. (\$1.00 each.)

mossy sorts mixed (Sutton's seed) - (\$5.00.)

- [muscoides]-Stormouth's Crimson Carpet mossy saxifrage. ( $\$ 1.00$ each.)

- [speciosa atropurpurea]-Purplish red. 1-11/2 feet. April-June. (\$5.00.)

- [stellaris]-Mounds of light green foliage, whitish starry flowers. (\$1.00 each.)

604 SCABIOSA caucasica (Blue Bonnet)-A choice summer flower of soft lavender-blue on stems $1 \frac{1}{2}$ to 2 feet high. Excellent as cut flowers. June to September. (\$3.50.)

- japonica--Clear blue flowers, 1 to $1 \frac{1}{2}$ inches in diameter. 2-3 feet. June-September.

859 SCUTELLARIA baicalensis coelestina-An alpine of dense bushy habit. Abundance of light blue flowers. 9-12 inches. July-August. (\$3.50.)

SEDUM-A group in which we are particularly interested. The most varied collection in this region is our aim. Among the very best rockery plants at our command.

- acre (Gold Moss)--Very low-growing, with small bright yellow flowers. May-July.

aizoon-A fast-growing plant. Clear yellow flowers. 1 foot. July-August.

- [alberti]-Pretty dwarf species, with yellow flowers. (\$4.00.)

- album (White Stone-Crop)-Very fine variety. 2-3 in. May-July.

- [anglicum]-White flowers. An exceedingly fast grower. Leares rounded. Dwarf. (\$3.50.)

- dasyphyllum (Leafy Stonecrop)-White flowers, very small fine foliage. Dwarf. May-July. (\$3.50.)

- ewersi-Rose-colored flowers. Sub-trailing. (\$4.00.)

864 - hispanicum-A pretty little species with pink flowers. 3-4 in. (\$3.00.)

865 - [ibericum]-Numerous pink or white flowers. Coarsely toothed leaves. 6 inches. (\$3.50.)

866 - kamtschaticum-A fast-growing distinctive species. Yellow flowers. Trailing habit.

867 - [ [ foll. var.]-Variegated distinctive foliage. (\$4.00.).

868 - lydium-Evergreen. Bronze foliage and pinkish flowers. 1-3 inches. June. $(\$ 3.50$.)

908 - maximowiczi (Amur Stonecrop)-Like aizoon only, if anything, a better grower. 1 foot. July.

869 - maximum (Great S.)-Tall, strong type. Purplish foliage. Flowers pale yellow. 1-11/2 feet. August-September.

870 - [murale]-Pretty, graceful species. 4 inches. (\$4.00.) 
871 - [obtusatum]-Very distinctire succulent rounded leares. Yellow flowers. 3 inches. (\$3.50.)

872 - oppositifolium.-Fast grower. (\$3.00.)

607 - [pruinatum forsterianum]-Bluish-green leares. Golden-yellow flowers in head-like clusters. We know no other variety like it. Very desirable.

873 - pulchellum (Texas S.)-Small leaves. Triangular heads of pink-white flowers in the spring. An excellent variety. An annual or biennial, but sows itself freely. (\$1.00.)

875 - reflexum (Jenny S.)-Fast grower. Fellow flowers. Gray-green leares. 1-6 inches. July. (\$3.00.)

608 - sarmentosum (String S.)-An excellent vellow flowered trailer. MayJuly.

609 - sexangulare-Much like S. acre.

610 - sieboldi-A slow grower but a rery valuable kind. Round, succulent, glaucous leares. Bright pink flowers in August and September. 9 in. (35 cents each.)

876 - [spathulatum]-Glaucous foliage. Large cockscomb-like heads of yellow flowers. 4 inches. (\$4.00.)

613 - spectabile (Showy Stone-crop)-Very pretty. Broad light green leares and large heads of showy rose flowers. Late fall. 18 inches.

$614--$ [Brilliant]-A bright show

878 - stahli.

611 - stoloniferum-Trailer. Flowers purplish-pink in July and August. 6 in.

612 - coccineum-Rosy-crimson form.

909 - telephium [atropurpureum]--Bold bronze foliage. Large clusters of buff flowers. $11 / 2$ feet. August-September.

879 - ternatum-Rather broad succulent leares borne in whorls of three. Flowers much like those of pulchellum.

SEMPERVIVUM-Here is another group of plants well fitted for rockery work. Live-for-Erers or Hens-and-Chickens, as they are called, increase by means of rosettes.

881 - sp.-A large variety. \$2.00.)

882 - [albertii]-Rosettes medium size. Flowers bright red. 8 inches. $(\$ 2.00$.)

914 - arachnoideum (Spiderweb Houseleek) - Silrery threads between the tips of the leares in the rosettes. Flowers bright red. 6 inches. $(\$ 2.00$.)

615 - [doellianum]-Blooms sparingly. Small hairy rosettes of pale green, tips of leaves tinted red. $(\$ 2.00$.)

616 - glaucum (Fuzzy Houseleek)-(\$2.00.)

617 - globiferum-Flattened rosettes, 2-3 inches across. Leares grey-green lightly tipped with brown. Pale rellow flowers. June. (\$2.00.)

618 - hirtum (cornutum)-Grey-green leares. Flowers pale vellow. (\$2.00.)

619 - [triste]-Green leares with markings of bright red-brown. Red flowers. (\$2.00.)

883 SENECIO pulcher-Striking erect plant. Large, red-purple flowers with yellow disk. Summer. 2-4 feet.

620 SIDALCEA [hybrida] (Mallow-wort)-Pretty mallow-like flowers. While this strain is supposed to contain pink, rose, red, salmon, lilac and heliotrope, all that have bloomed for us hare been pink-possibly a question of hardiness. A beautiful plant.

884 SILENE schafta (Autumn Catchfly)--Rosy-purple, trailing, good for rockery or border. June-September.

621 [STATICE latifolia]--See Limonium latifolium.

622 STATICE pseudoarmeria (False Thrift)-Rose and white. Fine border plant. 2 feet.

SWEET WILLIAM-See Dianthus barbatus.

886 [TALINUM calycinum] (Ozark Talinum)-"A new hardy succulent for rery dry sunny places. Small green tufts of thick needle-shaped leares from which arise 10-inch stems so slender that the flowers appear to float in the air. The red-purple and gold blossoms open only in the afternoon but are borne steadily throughout the summer from May till frost even during the worst heat and drought." (Shrere.) (50 cents each.) 
624 THALICTRUM minus adiantifolium (Maidenhair Meadowrue)-Foliage like the Maidenhair Fern. Small white flowers in June.

888 THYMUS serpyllum lanuginosus (Woolly-leaved Thyme) - A quicklyspreading plant, very nice for rockeries. Flowers reddish pink. 5 inches. June-August.

TRITOMA (Red Hot Poker Plant)-See Kniphofia.

891 TROLLIUS europaeus (European Globe Flower)-Flowers resemble the Buttercup. Lemon-yellow, on long stems. 2 feet. May-June. ( $\$ 3.50$.

$892-\longrightarrow$, Orange Globe---Flowers orange. (\$5.00.)

893 TUNICA saxifraga-A very nice rock plant with many small rosy-pink flowers. 6 inches. July-September.

895 VERONICA longifolia, Blue Ridge-Slender spikes of blue. Free bloomer. August-September. (\$3.50.)

$627-$ subsessilis-A showy variety and one of the best. Long dense spikes of deep blue flowers mid July to early September. 2-3 feet.

86 - spicata-Excellent plant for borders. Long spikes of bright blue flowers in June and July. $1 \frac{1}{2}$ feet.

628 - spuria-Blue flowers in long racemes. A dwarf tufted habit. May-June. 1 foot.

896 - teucrium [rupestris, Heavenly Blue]---Dwarf and spreading. (\$3.50.)

$897--$ [—, Trehani]-Brilliant blue flowers. 1 foot. May-June.

898 VIOLA [bosniaca]-A distinct alpine species. Small rose-magenta flowers. Very pretty.

899 - cornuta, G. Wermig-A good-sized blue flower produced freely all summer. An excellent rock plant.

900 - - Jersey Gem--Large and fragrant violet-colored blooms. A fine variety. May-November. (\$4.00.)

901 - $\longrightarrow$ Yellow Gem-Clear yellow and free flowering. We consider this an excellent companion plant for Jersey Gem.

903 - odorata, Gov. Herrick-Spring flowers in good numbers of a clear choice shade of blue.

629 YUCCA filamentosa (Common Yucca)-Very effective for plantings. Foliage sword-like. Spikes of large, fragrant, drooping, creamy-white flowers, 5 to 6 feet high in June and July.

$904--$ variegata-A very interesting form with leaves green and yellow. (\$1.00 each.) 


\section{Trees and Shrubs}

While we always have a few shrubs and trees on hand we do not make a practice of keeping ans quantity. We are rery glad, howerer, to execute orders for them. As we hare had numerous requests for this class of material, we are appending a price list. These items are offered subject to our ability to procure them. We feel, howerer, that it would be a rare case where we could not fill such an order.

These prices include all delivery charges so far as allowed under "General Directions."

Prices on other sizes giren on request.

All prices subject to change without notice.

\section{Deciduous Shrubs and Trees}

ABELIA chinensis [grandiflora], Chinese Abelia. 4 in. pots. ACANTHOPANAX pentaphyllum.

ACER buergerianum, Trident Maple. 12-18 in.

- dasycarpum [pyramidale], Pyramidal Silver Maple. 8-10 ft.

- ginnala, Amur Maple. 3-4 $\mathrm{ft}$.

- japonicum aureum, Golden Moon Maple. 21/2-3 ft.

- palmatum, Japanese Maple. 21/2-3 $\mathrm{ft}$.

- atropurpureum (Bloodleaf Japanese Maple). 21-30 in.

- pennsylvanicum, Striped Maple. 4-6 ft.

- platanoides, Norwar Maple. 6-8 ft.

- pseudoplatanus, Srcamore Maple. 8-10 ft.

- rubrum, Red Maple. 3-4 ft.

- saccharum, Sugar Maple. 4-6 ft.

- [Skinner's Cut-leaf Maple.] 6-8 ft.

AESCULUS glabra, Ohio Buckeye. 10-12 ft.

- hippocastanum, Horse Chestnut. 6-8 ft.

- - [flore pleno], Double White Flowering Horse Chestnut. 3-4 ft.

- parviflora, Bottlebrush Buckere-a shrub. 3-4 ft.

AILANTHUS glandulosa (Tree of Hearen). 4-5 $\mathrm{ft}$.

ALNUS incana, Speckled Alder. 10-12 ft.

pinnatifida, Featherleaf Alder. 8-10 ft.

AMELANCHIER canadensis, Down Shadblow. 18-24 in.

- laevis, Alleghany Shadblow. 2-3 ft.

- sp. [Dwarf Juneberry.] 9-12 in.

AMORPHA [angustifolia]. 2-3 ft.

- fruticosa, Indigobush. 2-3 ft.

- tennesseensis, Tennessee-indigo. 2-3 ft.

AMYGDALUS persica [alboplena], Double White Peach. $3-4 \mathrm{ft}$.

ARALIA spinosa, Devil's walkingstick. 18-24 in.

- - grandifolia, Great Black Chokeberry. 18-24 in.

AZALEA amoena. 10-12 in. diam.

- arborescens, Sweet Azalea. Clumps 18-24 in.

- calendulacea, Flame Azelea. Clumps 18-24 in.

- canescens, Piedmont Azalea. Clumps 18-24 in. 
- (Indian Azalea), Hakata Shiro. 10-12 in. diam.

- indica rosaeflora, Balsam Azalea. 8-10 in. diam.

- japonica, Japanese Azalea. 18-24 in.

- kaempferi, Torch Azalea. 18-24 in.

- kosteri, hybrid forms from kaempferi. 6-9 in.

ledifolia, Snow Azalea. 12-15 in. high.

- - [magnifica.] $12-15$ in. high

_- h. v. Sekidera. 12-15 in. high.

- linearifolia, Spider Azalea. 6-8 in.

- nudiflora, Pinxterbloom. 12-18 in.

obtusa kiusiana, (Kurume Azaleas), Benigiri. 10-12 in.

- - - (—- - 28 named varieties. 10-12 in.

- — - (— - 3 named rarieties. 10-12 in.

- occidentalis, Western Azalea. 2-21/2 ft.

- phoenicea, h. v. Maxwell. 12-15 in. diam.

- pontica, (Hardy Ghent Azaleas). 15-18 in.

- poukhanensis, Korean Azalea. 9-12 in.

- rosea, Downy Pinxterbloom. 18-24 in.

- schlippenbachi, Royal Azalea. 6-12 in.

- vaseyi, Pinkshell Azalea. 12-18 in.

- viscosa, Swamp Azalea. Clumps 18-24 in.

- yodogawa, Yodogawa Azalea. 18-24 in.

BACCHARIS halimifolia, Goundsel Bush. 21/2-31/2 ft.

BERBERIS ilicifolia, Holly Barberry. 11/2-2 ft.

- thunbergi, Japanese Barberry. 18-24 in.

- - [atropurpurea.] 2-yr. plants.

- minor, Box Barberry. $12-18$ in.

BETULA alba, European White Birch. 5-6 ft.

- - pendula [laciniata], Cut-leared European Weeping Birch. 5-6 ft.

- - purpurea, Purpleleaf White Birch. 10-12 ft.

- lenta, (Cherry or Black Birch). 10-12 ft.

- papyrifera, Canoe Birch. 5-6 ft.

- populifolia, Gray Birch. 8-10 ft.

BUDDLEIA [amplissima].

BUDDLEIA davidi magnifica, Oxeye Butterfly Bush. Strong.

- - superba, Juno Butterfly Bush.

- lindleyana.

CALliCARPA purpurea, Chinese Beautyberry. Strong.

CALLUNA vulgaris.

- - alba.

CALYCANTHUS floridus, Common Sweetshrub.

CARAGANA arborescens, Siberian Peatree. 2-3 ft.

CARPINUS betulus, European Hornbeam. 6-8 $\mathrm{ft}$.

CATALPA bignonioides, Common Catalpa. 8-10 ft.

- - nana, Umbrella Catalpa. 2-yr. heads.

- bungei, Manchurian Catalpa. 4-6 ft, heads; 15-18 in.

CEANOTHUS americanus, Jersey-Tea. $1 \mathrm{ft}$.

CELTIS occidentalis, Hackberry. 8-10 ft.

CEPHALANTHUS occidentalis, Common Button Bush. 
- - pendula, Weeping Dogwood. $6 \mathrm{ft}$.

- _ rubra, Red Flowering Dogwood. 3-4 ft.

- mas, Cornelian-Cherry. 2-3 ft.

- - aureo-elegantissima, Variegated C.-C. 2-3 ft.

- paniculata, Gray Dogwood. 18-24 in.

- sanguinea, Bloodtwig Dogwood. 2-3 ft.

- stolonifera, Red Osier. $2-3 \mathrm{ft}$.

CORYLOPSIS pauciflora, Buttercup Winterhazel. 2-3 $\mathrm{ft}$.

- spicata, Spike Winterhazel. 4-5 ft.

CORYLUS americana, American Hazelnut. 18-24 in.

10.50

- avellana, Filbert. 2-3 ft.

COTONEASTER acutifolia, Peking Cotoneaster. $2-3 \mathrm{ft}$.

- - villosula. $2-3 \mathrm{ft}$.

- bullata. 2-3 ft.

- dielsiana, Diels Cotoneaster. 18-24 in. pots. elegans. Pot grown.

- divaricata, Spreading Cotoneaster. 18-24 in. pots.

- foveolata. $12-18$ in.

- francheti. Pot grown. perpusilla. $12-18$ in. pots.

- [— wilsoni], Wilson Cotoneaster. 12-18 in. pots.

- hupehensis, Hupeh Cotoneaster. 6-9 in. pots.

- integerrima. European Cotoneaster. 6-9 in. pots.

- lucida. $2-3 \mathrm{ft}$.

- microphylla, Rockspray. Pot grown.

- nitens. $12-18$ in. pots.

- racemiflora soongarica. Pot grown.

- salicifolia, Willowleaf Cotoneaster. Pot grown.

- simonsi, Simons Cotoneaster. Pot grown.

- zabeli. 12-18 in. pots.

CRATAEGUS arkansana, Arkansas Hawthorn. 9-12 in.

. $2-3 \mathrm{ft}$.

- coccinea, Thicket $H$. 2-3 ft.

- cordata, Washington $\mathrm{H}$. 3-4 ft.

- crusgalli, Cockspur Thorn. 2-3 ft.

- monogyna alboplena, Double English H. 4-5 ft.

- punctata, Dotted Hawthorn. 3-4 ft. 
- - [rosea plena], (Double flowering Deutzia.)

- - _ [staphyleoides].

- - plena, Double Rose.

DIERVILLA rivularis, Georgia Bush Honeysuckle. 1-2 ft.

- sessilifolia, Southern Bush Honeysuckle. 2-3 ft.

- trifida, Dwarf Bush Honeysuckle. 6-12 in.

ELAEAGNUS angustifolia, Russian-Olive. 1-2 ft.

- longipes, Cherry Elaeagnus.

- umbellata, Autumn Elaeagnus. 2-3 ft.

ELSHOLTZIA stauntoni.

ENKIANTHUS campanulatas, Redrein Enkianthus. 18-24 in. $\quad 1.50$

- perulatus, white. E. $212 \frac{1}{-3} \mathrm{ft}$.

EUONYMUS, alatus. Winged Euonymus. 18-24 in.

- americanus, Brook E. $2-3 \mathrm{ft}$.

- bungeanus, Winterberry E. 2-3 $\mathrm{ft}$.

- europaeus, European Burning Bush. 2-3 ft.

- latifolius, Broadleaf Burning Bush. 2-3 ft.

- obovatus, Running E. 6-12 in.

- patens, Spreading E. 18-24 in.

- yedoensis, Yeddo E. 12-18 in.

EXOCHORDA grandiflora, Common Pearl Bush. 2-3 ft.

FAGUS americana, American Beech. 3-4 ft.

- sylvatica, European B. 5-6 ft.

_-__ [grandidentata], Sawtooth B. 8-10 ft.

- - heterophylla, Fernleaf B. 5-6 ft.

- pendula, Weeping B. 6-7 ft.

-_ purpurea, (Copper B.) 5-6 ft.

FORSYTIIIA intermedia, Border Forsythia. 2-3 ft.

- spectabilis. Showy border F.

- suspensa. Weeping F. 2-3 ft.

- - atrocaulis, Purple Stem F.

- - fortunei, Fortune F. 2-3 ft.

- viridissima, Greenstem F. $3-4 \mathrm{ft}$.

FRAXINUS americana, White Ash. 6-8 ft.

GAYLUSSACía baccata, Black Huckleberry. Clumps 12-18 in.

GINKGO biloba, Maidenhair-Tree. 6-8 ft.

GLEDITSIA triacanthos, Common Honey Locust. 4-5 ft.

HALESIA tetraptera, Great Silverbell.

HAMAMELIS virginiana, Common Witch Hazel. Standard.

- _- Lady Stanley.

- _ (William R. Smith).

HYDRANGEA arborescens, Smooth Hydrangea. 2-3 ft.

- - grandiflora, Snowhill. 2-3 ft.

- - - (Standard or Tree Form). 
ITEA virginica, Sweetspire. $\quad 1 \frac{1}{1 / 2}-2 \mathrm{ft}$.

JASMINUM humile, Italian Jasmine. Pot grown.

- nudiflorum, Winter J. Pot grown.

- cfficinale, Common White J. Pot grown.

JUGLANS cinerea, Butternut. 5-6 ft.

- nigra, Black Walnut. 6-8 ft.

KERRIA japonica, (Globe Flower).

KOELREUTERIA paniculata, Golden Rain Tree. 5-6 ft.

KOLKWITZIA amabilis, Beauty-bush. Field grown.

LABURNUM [rossii]. 6-8 ft.

- vu'gare, Goldenchain. $3-t \mathrm{ft}$.

LARIX dahurica, Dahurian Larch. 12-18 in.

- europaea, European L. 3-4 ft.

- leptolepis, Japanese L. $2-3 \mathrm{ft}$.

LESPEDEZA bicolor, Shrub Bushclover. 3-4 $\mathrm{ft}$.

- formesa, Purple Bushclover. Clumps.

LIGUSTRUM acuminatum. 2-3 ft.

- amurense, Amur Priret. 2-3 ft.

- [ibolium], Tbolium Privet. 2-3 ft.

- ibota, Ibota P. 2-3 ft.

- - regelianum, Regel P. 2-3 ft.

- [Lodense P.] 9-12 in.

— [argenteo-marginatum]. 18-24 in:

- - , [aureum], (Golden-leaved P).

- vulgare, European P. 2-3 ft.

LIRIODENDRON tulipifera, Tulip Tree. $6-8 \mathrm{ft}$.

LONICERA chrysantha, Coralline Honeysuckle. 2-3 ft.

- fragrantissima, Winter $H .2-3 \mathrm{ft}$.

- ledebouri. 2-3 $\mathrm{ft}$.

- maacki, Amur H. $2-3 \mathrm{ft}$.

- morrowi, Morrow H. 2-3 ft.

- ruprechtiana, Nanchurian $H$.

- tatarica alba. White Tatarian. H. 2-3 ft.

- - rosea, Rosy Tatarian H. 2-3 ft.

- - siberica, Red Tatarian H. 2-3 ft.

- [White Belle H.]. 2-3 ft.

MAGNOLIA acuminata, Cucumber Tree. 3-4 ft.

- glauca, Sweet Bay. 2-3 ft.

- kobus. 4-5 ft.

- liliflora, Purple Lily Magnolia. 21/2-3 ft.

- macrophylla, Bigleaf M. $\quad 2-3 \mathrm{ft}$.

- alexandrina. Alexander M. 21/2-3 ft.

lennei, Lenne M. 31/2-4 ft.

- [ - nigra ], Purple Lily M. 2-3 ft.

- stellata, Star M. 21/2-3 ft.

- tripetala, Umbrella M. 5-6 ft.

8.50

MALUS [arnoldiana], Arnold Crab. 3-4 ft.

atrosanguinea], Carmine C. $3-4 \mathrm{ft}$.

- mandshurica, Manchurian C. $2-3 \mathrm{ft}$.

- coronaria, Wild Sweet C. 3-4 ft.

- floribunda, Japanese Flowering C. 3-4 ft.

- halliana [parkmani], Parkman C. 3-4 ft.

- ioensis [plena], Betchel C. 3-4 ft.

- micromalus, Midget C. 3-4 ft. 
- [robusta,] Cherry C. 3-4 ft.

- sargenti, Sargent C. $3-4 \mathrm{ft}$.

- scheideckeri, Scheidecker C. 3-4 ft.

- sieboldi [calocarpa]. 2-3 ft.

- - [flore-pleno], (Double Chinese C.). 3-4 ft.

- theifera, Tea C. 3-4 ft.

- zumi, Zumi C. 3-4 ft.

MENZIESIA pilosa, Alleghany Menziesia. 18-24 in.

MORUS alba pendula, Weeping Mulberry.

-_ - tatarica, Russian Vulberry. 6-8 ft.

MYRICA carolinensis, Northern Bayberry.

- gale, Sreet gale. 18-24 in.

NYSSA sylvatica, Tupelo. 6-12 in.

OXYDENDRUM arboreum, Sourwood. $3-4 \mathrm{ft}$.

PHELLODENDRON amurense, Amur Corktree. 8-10 ft.

- chinense, Chinese C. 1-2 ft.

- sachalinense, Sakhalin C. 4-5 ft.

PHILADELPHUS, h. . . Albatre.

-, h. v. Avalanche.

-, h. v. Banniere.

-, h. v. Conquete.

- coronarius, Sweet Mock Orange. 2-3 ft.

- - [aureus], Golden M.

- - [florepleno], Double M. 4-5 ft.

-, h. r. (Enchantment).

-, h. v. Girandole.

- grandiflorus, Big Scentless M. 2-3 ft.

- lemoinei. 2-3 ft.

- - Manteau d'Hermine. 2-21/2 ft.

- [nivalis], Snowbank.

-, h. v. Splendens.

- [h. v. Virginal].

- [Zepher M.]. 2-3 ft.

PHYSOCARPUS intermedius, Mlinois Ninebark.

opulifolius, Common Ninebark. $2-3 \mathrm{ft}$.

PIERIS mariana, Staggerbush. 12-18 in.

PlatanUS occidentalis, American Plane Tree. 5-6 ft.

- orientalis, European Plane Tree. 10-12 ft.

POPULUS alba nivea, Silver Poplar. 6-8 $\mathrm{ft}$.

- bolleana. 5-6 ft.

- eugenei, Carolina P. 6-8 ft.

- nigra italica, Lombardy P. 6-8 ft.

- simoni, Simon P. 5-6 ft.

POTENTILLA fruticosa, Shrubbery Cinquefoil. 12-18 in.

- avium, Mazzard Cherry. 5-6 ft.

- besseyi, Bessey Cherry. 2-3 ft.

- cerasifera pissardi, Purpleleaf Plum. 4-5 ft.

- hortulana, Hortulan Plum. 4-5 ft.

- - . Japanese Flowering Cherry, 7 named vars. 3-4 ft.

$-\longrightarrow-1$, 2 named rars. $4-5 \mathrm{ft}$.

each 3.75

each 5.25

- maritima, Beach Plum. 1-2 ft.

- pumila, Sand Cherry. 2-3 ft.

- serrulata sachalinensis, Yama Cherry. 12-18 in.

- subhirtella [pendula], Shidare-Higan. 2-yr. heads.

- tomentosa, Nanking Cherry. 4-5 ft. 
PTELEA trifoliata, Common Hop Tree. $3-4 \mathrm{ft}$.

QUERCUS alba, White Oak. $6-8 \mathrm{ft}$.

- bicolor, Swamp White O. 6-8 $\mathrm{ft}$.

- coccinea, Scarlet O. 6-8 ft.

- palustris, Pin. O. $8-10 \mathrm{ft}$.

- phellos, Willow 0. 6-8 ft.

- prinus, Chestnut O. $8-10 \mathrm{ft}$.

- robor [fastigiata viridis], Green Pyramidal O. 10-12 ft.

- rubra, Common Red O.. 6-8 ft.

RHAMNUS caroliniana, Carolina Buckthorn. 3-4 ft.

- cathartica, Common B: 2-3 ft.

- dahurica, Dahurian B. 1.2 ft.

- frangula, Glossy B. 2-3 ft.

RHODORA canadensis, Rhodora. 15-18 in.

RHODOTYPOS, kerrioides, Jet Bead.

RHUS canadensis, Fragrant Sumac.

- copallina, Shining Sumac. 12-18 in.

- cotinus, Common Smoke Tree.

- glabra, Smooth Sumac. 1-2 ft.

- typhina, Staghorn S.

- _ laciniata, Shredder S.

RIBES alpinum, Nountain Currant. 11/2-2 ft.

- odoratum, Golden C. 2-3 ft

ROBINIA hispida, Roseacacia. Pot grown.

- kelseyi, Kelsey Locust. 18-21 in.

- pseudoacacia. Common Locust. 2-3 ft.

ROSA.- see special Rose list.

RUBUS laciniatus, Cutleaf Blackberry. 2-3 ft.

- occidentalis, Common Blackeap. 2-3 ft.

- odoratus, Flowering Raspberry.

- strigosus, Common Red Raspberry. 2-3 ft.

- [villosus], (Blackberry). 2-3 ft.

SALIX alba, White Willow. $3-4 \mathrm{ft}$.

- babylonica, Babylon Weeping W. 3-4 ft.

- caprea, Goat TT. 4-5 ft.

- [dolorosa], Wisconsin Weeping W. 8-10 ft.

- elegantissima, Thurlow Weeping W. $6-8 \mathrm{ft}$.

- incana, Rosemary WV. 3-4 ft.

- pentandra, Laurel W. 6-8 ft.

ina aurea, Russian Golden W. 6-8 ft.

- nigra, European E. 3-4 $\mathrm{ft}$.

- pubens, Scarlet Elder.

- racemosa, European Red E. $3 \mathrm{ft}$.

SORBARIA aitchisoni, Kashmir False-Spiraea. 3-4 ft. 
- - plena, Double Bridal Wreath.

- reevesiana, Reeres $S$.

lanceata, Double Reeres S. $2-3 \mathrm{ft}$.

- semperflorens, Perpetual S. $3-4 \mathrm{ft}$.

- thunbergi, Thunberg S. 1-2 ft.

- tomentosa, Hardhack. 2-3 ft.

- [trichocarpa]. Strong.

- vanhouttei, Vanhoutte S. $2-3 \mathrm{ft}$.

2.00

- veitchi. 18-24 in.

STAPHYLEA colchica, Colchis Bladdernut. 2-3 ft.

STYRAX japonica, Japanese Snowbell. 3-4 ft.

SYMPHORICARPOS [chenaulti]. 12-18 in.

- mollis, Spreading Snowberry. 2-3 ft.

- racemosus, Common Snowberry. 2-3 ft.

- variegatus, Variegated Coralberry. 2-3 ft.

- japonica, Japanese Tree L. 3-4 ft.

- josikaea, Hungarian L. 2-3 ft.

- [mixed hybrids]. 2-3 ft.

- persica, Persian L. 2-3 ft.

- - alba, White Persian L.

1.60

1.25

1.25

1.00

- - [laciniata]. 2-3 ft.

1.50

villosa, Late L. $2-3 \mathrm{ft}$. $2-3 \mathrm{ft}$.
vulgaris, Common Lilac. 2.

.75

1.00

- - alba, Common White Lilac.

1.25

- Alphonse Larallee. 18-24 in.

- Belle de Nancy.

1.25

- Bleuatre. $2-3 \mathrm{ft}$.

1.25

1.25

- Charles Joly.

1.00

- Charles the Tenth. 18-24 in.

1.25

- Condorcet. 2-3 ft.

1.25

- Congo.

1.25

1.25

- Dr. Maillot. 2-3 ft.

$1.00-3.00$

_- Jacques Callot.

-.- Jean Bart. 2-3 ft.

1.25

- Ludwig Spaeth.

- - Marie Legraye. 12-18 in.

1.25

1.50

1.25

1.50

1.25

- Mme. Abel Chatenay. 12-18 in.

1.25

Mme Casimir Périer.

- Mme. Lemoine.

- - Philémon.

- - President Carnot. 2-3 ft.

- _ Red Marley. 2-3 ft.

- — René Jarry-Desloges.

- - Vestale.

- William Robinson. 2-3 ft.

- - indica, India $T$.

TILIA americana, American Linden. 3-4 ft. 
- tomentosa, Silver L. $8-10 \mathrm{ft}$.

ULMUS americana, American Elm. $6-8 \mathrm{ft}$. 1.00

- campestris, English E. 8-10 ft.

- foliacea umbraculifera, Globe E. Standards. Specimens. $12 \mathrm{ft}$. 40.00

- wheatleyi, Wheatley E. $10-12 \mathrm{ft}$. 22.50

- glabra camperdowni, Camperdown (Weeping) E. $7 \mathrm{ft}$. 5.25

- [Moline Elm]. 6-8 ft.

VACCINIUM corymbosum, Highbush Blueberry. $2-3 \mathrm{ft}$. 1.50

- pallidum, Blueridge B. 18-24 in. 1.50

VIBURNUM acerifolium, Mapleleaf Viburnum. 12-18 in. $\quad .40$

— alnifolium, Hobblebush. $2-3 \mathrm{ft}$.

- americanum, American Cranberrybush. 18-24 in. $\quad 1.00$

- carlesi, Fragrant Viburnum. Strong. $\quad 3.00$

- cassinoides, Witherod. $2-3 \mathrm{ft}$. $\quad .60$

- dentatum, Arrowwood. $2-3 \mathrm{ft}$.

- dilatatum, Linden Viburnum. 2-3 ft. $\quad 1.00$

- lantana, Wayfaringtree. $2-3 \mathrm{ft}$. $\quad 1.00$

- lentago, Nannyberry. 2-3 ft. $\quad .60$

- nudum, Smooth Withe-Rod. $4-5 \mathrm{ft}$. 1.50

- opulus, European Cranberrybush.

- nanum, Dwarf Cranberrybush. $12-18 \mathrm{in.} \quad 1.00$

- sterile, Common Snowball.

- pubescens, Downy Viburnum. 2-21/2 ft. 1.25

- rhytidophyllum, Leatherleaf Viburnum. $\quad 1.00$

- sieboldi, Siebold Viburnum. 1-2 ft. $\quad .75$

- tomentosum, Double File Viburnum. $\quad .90$

- - [plicatum], Japanese Snowball. $\quad .90$

VITEX agnus-castus, Lilac Chaste-Tree. 2-3 ft. 1.00

- [macrophylla]. (Large-leared Chaste-Tree) Strong. $\quad .75$

WEIGELA amabilis, Rose Weigela. 18-24 in. 50

- [candida], (White Weigela).

— [Era Rathke]. 1-2 ft. $\quad .60$

- floribunda, Crimson Weigela. $\quad .75$

- [hybrida nana variegata], Dwarf Variegated Weigela. 75

- rosea, Pink Weigela. $2-3 \mathrm{ft}$. 1.00

- [folii purpureis]. $\quad .60$

ZANTHORHIZA apiifolia, Yellowroot. 12-18 in. $\quad .60$

ZENOBIA pulverulenta, Dusty Zenobia. 2-3 ft. 3.75 


\section{Broad-Leaved Evergreens}

ANDROMEDA polifolia, Bog Rosemary. 6-9 in.

ARCTOSTAPHYLOS uva-ursi, Bearberry. 6-9 in., 3 in. pots.

BERBERIS buxifolia, Magellan Barberry. Pot grown.

- [julianae]. Pot grown, 1-11/2 ft.

- verruculosa, Warty Barberry. Pot grown.

- sempervirens, Common Box, Bush Form. 15-18 in. high. 15 in. diam. 5.50 [BOXWOOD edging.] 5-6 in.

Per hundred 13.00

CALLUNA vulgaris, (Scoteh Heather). 6-12 in.

1.00

- _- alba, White Heather. 6-8 in.

- alporti, Alport Heather. Pot grown.

- - [aurea]. Pot grown.

- - [compacta.] Pot grown.

CHAMAEDAPHNE calyculata, Leatherleaf. 12-18 in.

DAPHNE cneorum, Rose Daphne. 8-10 in.

EUONYMUS patens, Spreading Euonymus. 11/2-2 ft.

GALAX aphylla, Galax. Strong.

GAYLUSSACIA brachycera, Box Huckleberry. 2 in. pots.

ILEX crenata, Japanese Holly. 2-21/2 ft.

- glabra, Inkberry. 12-18 in.

- opaca, American Holly. 21/2-3 ft.

KALMIA angustifolia, Lambkill. Clumps. 6-9 in.

- latifolia, Mountain Laurel. Clumps. 2-3 ft.

- polifolia, Bog Kalmia. 8-12 in.

LEDUM groenlandicum, True Labrador Tea. 12-18 in.

LEIOPHYLLUM buxifolium, Box Sandmyrtle. 6-9 in.

- - prostratum, Allegheny S. 3-6 in.

LEUCOTHOE catesbaei, Drooping Leucothoe. Clumps. 21/2-3 ft.

MAHONIA aquifolium, Oregon Hollygrape. 2-21/2 $\mathrm{ft}$.

PACHISTIMA canbyi. 6-9 in.

PACHYSANDRA terminalis, (Japanese Spurge). $2 \mathrm{yl}$.

PIERIS floribunda, Mountain Andromeda. 12-18 in.

RHODODENDRON carolinianum, Carolina Rhodendron. Clumps. 18-24 in.

- $\longrightarrow$, hort. var, album. $2 \mathrm{ft}$.

$-\longrightarrow$ caractacus. $11 / 2 \mathrm{ft}$.

$-\longrightarrow$ Charles Bagley. $3 \mathrm{ft}$.

$-\square-$ Charles Dickens. ${ }^{21 / 2}$

$-\square-$ Everest. $11 / 2 \mathrm{ft}$. $11 / 2 \mathrm{ft}$.

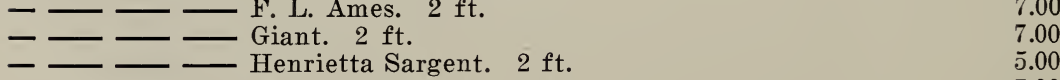

$-\longrightarrow$ Ignatius Sargent. $2 \mathrm{ft}$.

--- Kettledrum. $2 \mathrm{ft}$.

$-\longrightarrow$ Mrs. Charles Sargent. $2 \mathrm{ft}$.

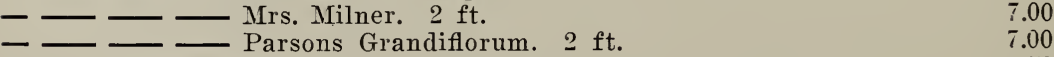

二- - Parsons Grandiflorum. $2 \mathrm{ft.} \quad \begin{aligned} & 7.00 \\ & \text { Parsons Gloriosa. 11/2 } \mathrm{ft.}\end{aligned}$

$-\square-$ parpons Gloum grandiflorum. $2 \mathrm{ft}$.

-- Snow White. $2 \frac{1}{2} \mathrm{ft}$.

- caucasicum, hort. rar. Boule de Neige. $1 \frac{1}{2} \mathrm{ft}$. diam. 
- dahuricum, Dahurian Rhododendron. 18-24 in.

- laetivirens, Wilson Rhododendron. $2-21 / 2 \mathrm{ft}$.

- maximum, Rosebay Rhododendron. Clumps. $2-3 \mathrm{ft}$. roseum, Pink Rosebay Rhododendron. ? ft.

- - X catawbiense, hort. var. Delicatissimum. $1^{1 / 2} \mathrm{ft}$.

- micranthum, Manchurian Rhododendron. 18-2t in.

- mucronulatum, Korean Rhododendron. 12-1s in.

- smirnori. 15-15 in.

SHORTIA galacifolia, Oconee Bells. Strong.

VINCA minor, Common Periwinkle. Strong.

- - alba, White Common Periwinkle. 21, in. pots. 


\section{Narrow-Leaved Evergreens}

ABIES balsamea, Balsam Fir. $3-4 \mathrm{ft}$.

- concolor, White Fir. 3-4 ft.

fraseri, Fraser Fir. 3-4 $\mathrm{ft}$.

- homolepis, Nikko Fir.. 3-4 ft.

- nordmanniana, Nordmann Fir. $3-4 \mathrm{ft}$.

- veitchi, Veitch Fir. $7 \mathrm{ft}$.

CHAMAECYPARIS lawsoniana alumi, Scarab Cypress. $3-31 / 2 \mathrm{ft}$. 8.50

- - h. v. Triomphe de Boskoop. $3-31 / 2 \mathrm{ft}$.

obtusa, Hinoki Cypress. 21/2-3 ft.

aurea [Youngi] (Young's Golden Hinoki Cypress). 21/2-3 ft.

- [crippsi]. 2-21/2 ft.

8.50

[erecta.] $21 / 2-3 \mathrm{ft}$.

- pisifera, Sawara Retinospora. 3-4 ft.

- - - [argentea], Silvertip Retinospora. $2 \frac{1}{2}-3 \mathrm{ft}$.

- - [sulphurea.] 12-15 in. diam.

- - squarrosa, Moss Retinospora. 2-21/2 ft.

5.00

3.00

4.50

6.00

JUNIPERUS chinensis, Chinese juniper. 3-4 ft.

- [albo-variegata], (Silver-tipped J.) $2-2 \frac{1}{2} \mathrm{ft}$.

- [columnaris]. $21 / 2-3 \mathrm{ft}$.

- - pfitzeriana, Pfitzer. J. 18-24 in.

- communis, Common J. 11/2-2 ft.

- aurea, Golden J. 15-18 in.

3.50

2.25

- - stricta, Spiny Greek J. 18-24 in.

- japonica, Japanese J. (White variegated Japanese J.) $1 \frac{1}{2}-2 \mathrm{ft}$.

- - [aurea], Golden Japanese J. 3-31/2 ft.

sabina, Savin. 12-18 in.

- — cupressifolia, Cypress S. $2-21 / 2 \mathrm{ft}$.

- - fastigiata, Column S. 3-4 ft.

- sphaerica. $3-31 / 2 \mathrm{ft}$.

- virginiana, Red Cedar. 3-4 ft.

- - [burki]. 3-4 $\mathrm{ft}$.

- glauca, Silver R. C. 3-4 ft.

- - globosa, Globe R. C. $18 \times 18$ in. 
- - pendula, Weeping R. C. 21/2-3 ft.

- - [smithi]. 3-312 ft.

PICEA canadensis, White Spruce. 2-3 ft.

- - - (Dwarf rariety). 12-15 in.

- englemanni, Engelmann $S$.

excelsa, Norwar s. $3-4 \mathrm{ft}$.

- [inversa], (Inrerted S.) $34 \mathrm{ft}$.

- [koyamai]. 15-24 in.

- pungens, Green Colorado s. $3 \mathrm{ft}$.

- - glauca, Blue Colorado $\mathrm{s}$. $2-3 \mathrm{ft}$.

PIXL'S banksiana, Jack Pine. $2-3 \mathrm{ft}$

cembra, Smiss Stone P. - -3 ft.

- densiflora. Japanese Red. P. $3-4 \mathrm{ft}$.

- jeffreyi. 18-24 in.

- koraiensis. $2-3 \mathrm{ft}$.

- [massoniana]. $3-1 \mathrm{ft}$.

- montana, Swiss Mountain P. $3-1 \mathrm{ft}$.

- monticola, Western White P. $3-4 \mathrm{ft}$.

- ponderosa, Western Fellow $P$. $j-\frac{1}{t}$ t.

- strobus, White $\dot{P} .3 \pm \mathrm{ft}$.

- sylrestris, Scoteh P. 3-31/2 ft.

- thunbergi, Japanese Black $\mathbb{P}$. its ft.

TAXUS canadensis, Canada Iew. 12-15 in.

- cuspidata, Japanese $\Gamma$. 18-24 in.

- - [capitata], (upright Japanese I.) 21/2 ft.

- - nana, Dwarf Japanese $I .12$ in. spread.

THUJA occidentalis, American Arborvitae. $3-\frac{1}{4}$.

- Columbia, Columbia A. 18-24 in. 
- orientalis, Oriental Arborvitae. $2 \frac{1}{2}-3 \mathrm{ft}$.

- - [aurea conspicua], Goldspire A. 11/2-2 ft.

- - [aurea nana], Berckman's Golden A. $1 \frac{11}{2} \mathrm{ft}$.

- standishi, Standish Arborvitae. 2-21/2 ft.

TSUGA canadensis, Canada Hemlock. 2-3 ft.

- - - $3-4 \mathrm{ft}$.

- - gracilis, Slender Canada H. $2 \frac{1}{2} \mathrm{ft}$.

- - pendula, Sargent Weeping $H$. 11/2-2 ft.

- caroliniana, Carolina $\mathrm{H}$. $3-4 \mathrm{ft}$.

- diversifolia, Japanese H. 21/2-3 ft. 


\section{Roses}

As with the rest of the shrubs we do not make a practice of carrying mans rose bushes on hand. Howerer, we invite orders for them and will supply same, always subject to our ability to procure them. Prices subject to change without notice.

We feel that the appended list presents an extremely interesting group of species and rarieties.

The following abbreriations are used to gire a general idea of the color. Combinations of these abbreviations can be easily read.
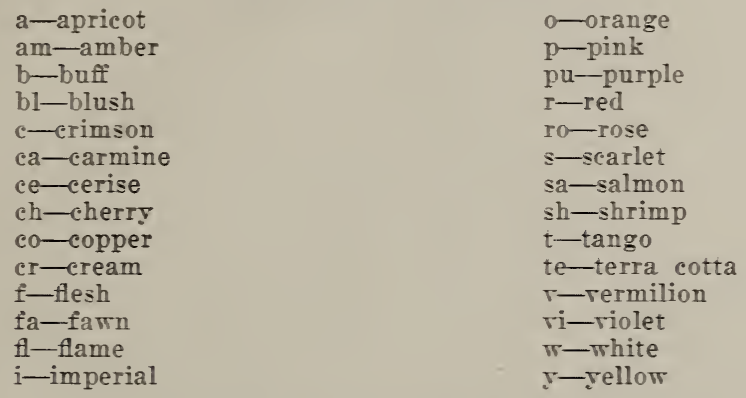

\section{A. AUSTRIAN AND HYBRID BRIER ROSES}

Austrian Copper, r.

Beaute de Lron, r.

Harrison's Yellow, s.
$\$ \begin{array}{ll}.75 & \text { Juliet, ro. } \\ .75 & \text { Persian Iellow, } 5 . \\ .75 & \text { Sonnenlicht, } 5 .\end{array}$

$\$ .75$

.75

1.00

\section{B. CLIMBING ROSES}

Alberic Barbier,. .

Albertine, $p$.

Alida Lorett, $p$.

American Pillar, p.

Ariateur Bleriot,.

Ben Stad, cr. $W$.

Bess Lorett, r.

Bonnie Prince, $\pi$.

Christine Wright, ro. p.

Clematis, $r$.

Climbing American Beauty, c.

Climbing Gruss an Teplitz, c.

Crimson Rambler, $\mathrm{r}$.

Doreas, p.

Dorothr Perkins, p.

Dr. Robert Hues, c.

Dr. W. Tan Fleet, f. p.

Elizabeth Zeigler, ro. p.

Emily Gray, \$.

Ernestine Cosme, p.

Excelsa, c.

Freedom, w.

Gardenia, er.

Gen. John Pershing, p. (dark)

Ghislaine de Feligonde, 5 .

Gloire de Dijon, b.

Heart of Gold, c.
$\$ 1.00$ Hiawatha, ca.

1.00 Me de France, c.

Lady Gar, p. $\quad .75$

Mary Lorett, $w$.

Mary Tallace, ro. p. $\quad .75$

Max Graf, p. 1.00

Mrs. M. H. Walsh, W.

Papa Gouchault, e. $\quad .75$

Papa Rouillard, r. $\quad 1.50$

Paul's Scarlet Climber, s.

Phrllis Bide, $\mathrm{y}$. 1.50

Pillar of Gold, $x$.

Princess Louise, pu. $\quad 1.50$

Professor C. S. Sargent, I.. .5

Roserie, ca. $\quad .5$

Shower of Gold, $x$.

Silver Moon, w.

Snowtlake, $\pi$. $\quad 1.50$

Solarium, s. $\quad 1.00$

Star of Persia, s. $\quad 1.00$

Tausendschoen, p. $\quad . .5$

The Beacon, r. $\quad 1.00$

Victory, sa. p. $\quad 2.50$

White Dorothy Perkins, w. .75

Wichuraiana, $\pi$. 


\section{DAMASK AND GALLICA OR FRENCH ROSES}

$\$ 1.00$ each

Belle des Jardins, c.

Commandant Beaurepaire, ro. p.

Georges Vibert, c.

Henri Fouquier, ro. p.

Lady Curzon, ro. p.

Mme. D'Hebray, w.

Oeillet Flamand, p.
Perle des Panachées, w. ro. and c.

President Dutailly, ca., pu.

Rosa mundi, w., p. and r.

Tri-colore de Flandre, w., r. and c.

York and Lancaster, r. and w.

- Parfait, p., r. and c.

Panachée Double, ro. and w.

\section{DWARF STANDARDS}

$\$ 2.00$ each

Chantillon

Gruss an Aachen

Orleans

\section{E. HYBRID PERPETUALS}

$\$ 1.00$ each, unless otherwise specified

Alfred Colomb, c.

American Beauty, ca.

Anna de Diesbach, ca. ro.

Baron de Bonstetten, c.

Baroness Rothschild, ro.

Baron Girod de L'Ain, c.

Candeur Lyonnais, w.

Captain Christy, f. p.

Captain Hayward, s.

Clio, f. p.

Earl of Dufferin, c.

Fisher Holmes, s.

Frau Karl Druschki, w.

General Jacqueminot, e.

George Arends, ro.

George Dickson, c.

Gloire de Chedane Guinoisseau, v. r.
Gloire, Lyonnaise, w. and y.

Heinrich Munch, p.

Henry Nevard, s.

Hugh Dickson, r.

$\$ 1.50$

$\$ 1.50$ John Hopper, ro.

Magna Charta, ea. p.

Margaret Dickson, w. and ro.

Marshall P. Wilder, r.

Mme. Albert Barbier, w. and f. p.

Mrs. John Laing, p.

Mrs. R. G. Sharman Crawford, ro. p.

Paul Neyron, r.

Prince Camille de Rohan, r.

Roger Lambelin, c. and w.

Ulrich Brunner, r.

\section{F. HYBRID SWEET BRIER ROSES}

When well established, these are very hardy.

$\$ 1.00$ each

Amy Robsart, ro.

Anne of Geirstein, c.

Bradwardine, $\mathrm{p}$.

Brenda, p.

Catherine Seyton, ro.

Edith Bellenden, ro.

Flora MeIvor, w.

Green Mantle, r.
Jeannie Deans, c.

Julia Mannering, p.

Lady Penzance, co.

Lord Penzance, fa.

Lucy Ashton, w.

Lucy Bertram, c.

Refulgens, s.

Rose Bradwardine, ro. p.

\section{G. TEAS AND HYBRID TEAS}

$\$ 1.00$ each, unless otherwise specified

Admiral Ward, c.

Admiration, cr. w. and o. v.

Amalie de Grieff, ro. w.

Amelie de Bethune, r.

America, ro. p.

Angele Pernet, t.
Annie Laurie, f. p.

Antoine Rivoire, f. p.

Arthur R. Goodwin, o. p.

Aspirant Marcel Rouyer, o.
$\$ 2.50$

Bedford Crimson, s. 
Belle Cuirree, ro.

Bessie Chaplin, p.

Betty, ro.

Betty Uprichard, sa, p.

British Queen, w.

Capitaine Georges Dessirier, c., 1.50

Captain Ronald Clerk, s. o. 2.50

Caroline Testout, ro.

Cechoslaria, $w$.

Chateau de. Clos Vougeot, c.

Cheerful, p.

Christine, $y$.

Clara Curtis, 5 .

Clereland, ro.

Columbia, ro. $\mathrm{p}$.

Comtesse de Casagne, p.

Constance, $\bar{y}$.

Cornelis Timmermans, p.

Crusader, c.

Cuba, s.

Dame Edith Helen, p.

Dean Hole, ea.

Diadem, 0.

Doris Traylor, i. p.

Dorothr Page-Roberts, p.

Duchess of Sutherland, ro. p.

Duchess of Wellington, $y$.

Earl Beatty, c.

Earl Haig, c.

Ecarlate, ro.

Edel, $w$.

Edgar M. Burnett, f. p.

Edith Part, r. and $y$.

Edward Mawler, c.

Eldorado, 5 .

Elegante, $\mathbf{x}$.

Elsie Beckwith, ro. p.

Emile Charles, r.

Emma Wright, 5 .

E. P. H. Kingma, o.

Ethel James, ea. p.

Etienne Rebeillard, ca. p.

Etoile de Feu, o. p.

Etoile de France, c.

Felicity, p.

Feu Joseph Loormans, y.

Florence L. Izzard, $\boldsymbol{5}$.

Florence Pemberton, p. w.

Frances Gaunt, a.

Francis Scott Key, c.

Frank Reader, r.

Frank W. Dunlop, r. p.

Frau Felix Tonnar, ro.

1.50

1.50

2.50

1.50

General MacArthur, s.

General-Superior Arnold Janssen, ca.

George C. Waud, r.

Golden Emblem, s.

Golden Ophelia, 0 .

Gorgeous, 5 .

1.50
Grange Colomb, w.

Hadley, c.

Harry Kirk (tea), $\mathbf{y}$.

Hoosier Beauty, s.

H. V. Machin, e.

Imperial Potentate, ro. p.

Independence Day, o.

Innocence, $w$.

Irish Charity, s.

1.50

Irish Charm, bl. p.

1.50

Irish Courage, p. and o.

1.50

Irish Elegance, 0.

Irish Fireflame, o.

Irish Hope, c.

Irish Morn, i. p.

Irish Simplicity, $\pi$.

Irish Sweetness, r.

Isobel, $\mathrm{p}$.

James Walley, a.

Janet, 0 .

John Russell, c.

Jonkheer J. L. Mock, i. p.

Joseph Hill, sa. p.

Josephine Thomas, 0 .

J. Otto Thilow, ro. p.

Kaiserin Augusta Victoria, $\pi$.

Killarney, p.

Killarney Brilliant, c. p.

Killarney Double White, $\pi$.

Killarney Queen, ce. p.

K. of K., s.

La Champagne, o.

Ladr Alice Stanley, ro.

1.50 Lady Ashtown, ca. p.

Lady Dixon Hartland, sa. p. $\quad 1.50$

1.50 Lady Florence Stronge, ro. $\quad 1.50$

Lads Hillingdon (tea), $\mathbf{s}$.

Lady Inchiquin, r.

Lady Margaret Stewart, o.

Lady Mary Elizabeth, ea. p.

Lady Pirrie, o.

Lady Roundway, 0.

Lady Ursula, f. p.

Lady Teres, ro. p.

La France, p.

1.50 La Tosca, p.

Laurent Carle, c.

Lieutenant Chaure, c.

Lilian Moore, $\mathrm{x}$.

2.00 Lord Allenby, c.

Lord Charlemont, c.

Lord Lambourne, $\mathbf{5}$.

Los Angeles, fl. p.

Louise Catherine Breslau, sh. p.

Lulu, r.

Mabel Morse, y.

Mabel Prentice, r. p.

Mabel Turner, w. and ca. 
Maman Cochet Pink (tea), p.

Maman Cochet White (tea), w.

Margaret Dickson Hamill, y.

Margaret Horton, y.

Margaret MeGredy, r. to ca. ro. 3.00

Marquise de Sinety, y.

Mary, Countess of Mchester, ro. p.

Mary Pickford, y.

1.50

Maud Cuming, p.

2.50

Miss Cynthia Forde, p.

Miss Lolita Armour, r.

Mme. Abel Chatenay, p.

Mme. Alexander Dreux, y.

Mme. Butterfly, p.

Mme. Charles Lutaud, y.

Mme. Edmond Rostand, f. p.

Mme. Edouard Herriot, r.

Mme. Jules Bouche, w.

Mme. Jules Grolez, ro.

Mme. Leon Pain, o.

Mme. Melanie Soupert, $y$.

Mme. Poincaire, sa. p.

Mme. Ravary, y.

Mme. Segond Weber, sa. p.

Mrs. Aaron Ward, y.

Mrs. A. C. Barraclough, ea. p. 2.50

Mrs. Arthur Robert Waddell, sa. p.

Mrs. Beckwith, y.

Mrs. Calvin Coolidge, y.

Mrs. Charles Lamplough, y.

Mrs. Charles Russell, ro. ca.

Mrs. C. W. Dunbar Buller, ro. ca.

Mrs. C. W. Edwards, s.

Mrs. Dunlop Best, r. a.

Mrs. Erskine Pembroke Thom, y. 2.00

Mrs. Franklin Dennison, w. and y.

Mrs. F. W. Vanderbilt, r.

Mrs. Henry Bowles, sa. p.

Mrs. Henry Morse, p.

Mrs. Herbert Stevens, w.

Mrs. H. S. Prentiss Nichols, p. $\quad 1.50$

Mrs. Lovell Swisher, sa. p. $\quad 2.00$

Mrs. J. C. Ainsworth, p.

Mrs. R. B. Molony, ca. p.

Mrs. Redford, o.

Mrs. S. K. Rindge, y.

Mrs. Talbot O'Farrell, c. and o. 2.50

Mrs. T. J. English, a. and am. $\quad 2.50$

Mrs. Tom Smith, r. $\quad 2.00$

Mrs. Wakefield Christie-Miller, p.

Mrs. Wemyss Quin, o.

Mrs. W. E. Nickerson, y.

Mrs. William C. Egan, p.

Muriel Wilson (tea), w.

Nederland, r.

Norman Lambert, o.

Ophelia, f. p.
Padre, s.

Patience, o.

Pax Labor, y.

Pharisaer, ro. p. and sa. p.

Pink Pearl, ce. p.

Premier, p.

President Cherioux, r. and $\mathrm{p}$.

Prince de Bulgarie, f. p.

Princess Ghika (tea), r.

Queen of Fragrance, p.

Radiance, c. p.

Red Radiance, r.

Reims, w. and 0 .

Rev. F. Page Roberts, r. to y. 2.00

Richard E. West, y. $\quad 2.50$

Richmond, s.

Rosabel Walker, c.

Roselandia, 0 .

Rose Marie, ro. p.

Sensation, c.

Severine, r.

Shot Silk, ro.

Sir David Davis, c.

Souvenir de Claudius Pernet, y.

Souvenir de F. Bohe, o. sa.

Souvenir de Francois Mercier, ro. 2.50

Souvenir de George Beckwith, sa. p. and $y$.

Souvenir de Georges Pernet, te.

Souvenir de H. A. Verschuren, y.

Souvenir du President Carnot, f. p.

Soyecourt, r.

2.50

S. S. Pennock, r.

Sunburst, $y$.

Sunstar, y. and c.

1.50

Sybil, sa.

Templar, r.

The General, r.

The Queen Alexandra, v.

Tim Page, y.

Una Wallace, ro.

Vesuvius, c.

Victor Waddilove, o. and ca. p. 1.50

Ville de Paris, $y$.

2.00

Waltham Flame, te.

2.50

W. C. Gaunt, e.

Wilhelm Kordes, y. and r.

William E. Wallace, y.

William R. Smith (tea), w. and ro.

Willowmere, sh. p.

H. MISCELLANEOUS ROSE SPECIES

$\$ 1.00$ each, unless otherwise specified

acicularis, Prickly Rose, ro. p.

[alberti], w.

[alba], w.

[arvensis], w. 
Tella, Solitary Rose, p.

llauda, Meadow Rose, p. ranina, Dogbrier, p.

[carolina], ro. p.

caudata, r.

coriifolia, Leatherleaf R., p.

- froebeli, w.

damascena, Damask R., ro. p.

- [trigintipetala], ro. p.

daridi, Darid R., p.

darurica, Dahurian R., p.

ecae, Eca R., r.

foliolosa, w.

gallica, French R., p. to c.

- [conditorum], p.

- [splendens], ca.

gymnocarpa, Bald-Hip R., p.

helenae. $w$.

[hibernica], p.

[- graresi]

hugonis, $r$.

humilis, Pasture R., p.

[koreana], w. and p.

cheritierana, Bourcault R., c.

lucida, Tirginia R., p.

[macrantha]. p.

maximowiczziana jacki, $\pi$.

[mollis], p.

[morica], p.

moschata [alba], White Musk R., w.

- floribunda, w.

moresi, Mores R., r.

- catharensis, Cathar R., p.

- [platrphrlla], c. multil,racteata, p.

.60 multiflora, Japanese R., w.

.60 nitida, Bristly R., p.

.60 odorata, Tea R., p. omeiensis, Mt. Omei R., w.

- (vellow fruit), $w$.

- [pteracantha], $w$.

palustris, Swamp R., ro. p. pendulina [pubescens], r.

pisocarpa, $\mathrm{p}$.

pomifera, p.

- [multiplex], p.

pratti, Pratt R., p.

rubiginosa, Sweet Brier R.

- [magnifica]. p.

rubrifolia, Redleaf R., p.

saturata, Coral Rose, r.

[sericea], w.

setigera, Prarie R., p.

- tomentosa, p.

setipoda, Nodfruit R., p.

.60

.60

spinosissima, Scoteh R., w. or f. p.

- altaica, Altai R., $r$.

- [fulgens], p.

sweginzowi, p.

[rirginiana alba], White

Tirginia R., $\pi$.

[rebbiana], p.

willmottiae, ro.

woodsifendleri, p.

xanthina, Korean R., ז.

- [Allard], r.

- [normalis], 5 .

\section{MOSS ROSES}

All hardy

75 cents each

Baron de Tassenaer, c.

Blanche Moreau, $\pi$.

Crested Moss, ro. p.

Henrs Martin, c.

La Neige, $w$.

Old Pink Moss, ro.

Princess Adelaide, ro.

Red Moss, r.

Salet, p.

\section{J. PERPETUAL FLOWERING BEDDING ROSES}

75 cents each

Gruss an Aachen, f. p.

Hermosa, p.

Gruss an Teplitz, s.

\section{K. POLYANTHA OR BABY RAMBLERS}

75 cents each, unless otherwise noted

Aennchen Muller, $p$

Alice Amos, ch. p.

Cecil Brunner, ro. p.

Chatillon Rose, p.

Clotilde Soupert, $\mathrm{w}$. and p.

Coral Cluster, p.

Ellen Poulsen, ro. p.
Erna Teschendorff, $\mathbf{r}$.

$\$ 1.50$ Era Teschendorff, $\pi$.

George Elger, ז.

Helene Leenders, $p$.

Ideal, r.

Katharine Zeimet, $\pi$.

Lads Reading, r. 
Maman Levavasseur, $p$.

Miss Edith Carell, r.

Salmon Queen, sa. p.

Mme. Cecile Brunner, p.

Superba, ea.

Mme. Norbert Levavasseur, c

Triomphe Orleanais, r.

Mrs. Wm. H. Cutbush, p.

Yvonne Rabier, w.

\section{PROVENCE OR CABBAGE ROSES \\ (Rosa centifolia) \\ $\$ 1.00$ each}

Cabbage, ro. p.

Konigin von Danemark, f. p.

La Noblesse, ro. and ca.

Oeillet, p.

Petite de Hollande, ro.
Pompon de Bourgogne, $p$

Red Provence, r.

Unique Blanche, w.

Vierge de Clery, w.

\section{RAMANAS OR RUGOSA ROSES AND HYBRIDS}

$\$ 1.00$ each, unless otherwise specified

Agnes, y.

Amelie Gravereaux, r.

Arnold, r.

Belle Poitevine, $\mathrm{p}$.

Blanc Double de Coubert, w. $\quad .75$

Conrad Ferdinand Meyer, ro. $\quad .75$

F. J. Grootendorst (hybrid), o. r.

Hansa, vi.

Hildenbrandseck, ca.

Mme. Charles Fred'k Worth, ro. ca.

Mme. Georges Bruant, w.

Mme. Julien Potin, f. p.

New Century, f. p.
Nova Zembla, w. and p.

Rose a Parfum de L'Hay, c.

Roseraie de L'Hay, r.

Rugosa, ro. ca.

- alba, w.

albo-plena, w.

- repens alba, w.

- rubro-plena, c. p.

Schneelicht, w.

Scneezwerg, w.

Sir Thomas Lipton, w.

Turkes Rugosa Samling sa. p. $\quad 1.50$

\section{N. TREE SHAPED ROSES}

$\$ 3.50$ each unless otherwise specified

(The colors will be found under the List of Hybrid Teas and Teas and Hybrid Perpetuals)

$\begin{array}{ll}\text { Betty } & \$ 3.00 \\ \text { Betty Uprichard } & \\ \text { Charles K. Douglas } & \\ \text { Columbia } & \\ \text { Eldorado } & \\ \text { Etoile de Hollande } & \\ \text { Francis Scott Key } & \\ \text { Frau Karl Druschki } & \\ \text { General MacArthur } & \\ \text { General-Superior Arnold Janssen } \\ \text { Gruss an Aachen } \\ \text { Gruss an Teplitz } \\ \text { Independence Day } \\ \text { Jonkheer J. L. Mock } \\ \text { Kaiserin Augusta Victoria. } \\ \text { Killarney Double White } \\ \text { Killarney Queen } \\ \text { Lady Alice Stanley } \\ \text { Lady Ashtown } \\ \text { Lady Hillingdon } \\ \text { Lady Ursula } \\ \text { La Tosca } \\ \text { Los Angeles }\end{array}$

Magna Charta

Miss Cynthia Forde

Miss Lolita Armour

Mme. Butterfly

Mme. Caroline Testout

Mme. Edouard Herriot

Mme. Leon Pain

Mrs. Aaron Ward

Mrs. A. R. Waddell

Mrs. Henry Morse

Mrs. John Laing

Mrs. Wakefield Christie-Miller

Ophelia

Radiance

Red Radiance

Red Star

Killarney Queen

Rev. F. Page-Roberts

Rose Marie

Lady Ashtown

Sourenir de Claudius Pernet

Souvenir de Georges Pernet

Souvenir de H. A. Verschuren

Ulrich Brunner

Victory 


\section{Vines, Creepers and Climbers}

(For Climbing Roses see the Special Rose List)

ACTINIDIA arguta, Bower A. 3 yr.

- polygama, Silver Vine. Pot grown.

AKEBIA quinata, Fiveleaf A. 3 yr.

AMPELOPSIS heterophylla, Porcelain A. $3 \mathrm{yr}$.

- quinquefolia, Virginia Creeper. $3 \mathrm{yr}$.

tricuspidata, Japanese Creeper. 3 yr.

- - [lowi], Geranium Creeper.

- - [purpurea], Purple Creeper. Pot grown.

- - vitacea, Thicket Creeper. 4 yr.

ARISTOLOCHIA sipho, Dutchman's-Pipe.

BIGNONIA grandiflora, Chinese Trumpet Creeper. Pot grown.

- radicans, Trumpet C. $3 \mathrm{yr}$.

CELASTRUS orbiculatus punctatus, Christmas Bittersweet. 1-2 ft.

- scandens, American B. 3 yr.

CLEMATIS crispa, Curly C. 2 yr.

- hybrids, Duchess of Edinburgh.

- - Henry. 2 yr.

- - Madame Baron Veillard. 2 yr. Pot grown.

- Madame Edouard Andre.

Ramona. 2 yr. Pot grown.

- jackmani, Jackman C.

- montana [rubens]. [undulata].

- paniculata, Sweet Autumn Clematis. extra.

- texensis, Scarlet C. 2 yr.

- virginiana, Virgins-Bower. Strong.

EUONYMUS obovatus, Running E. 6-12 in.

- radicans, Wintercreeper. 2 yr.

- - [acuta].

- - [argenteo-marginatus], Silveredge W. 3 yr.

- - [carrierei], Glossy W. 3 yr.

- - [colorata]. $15-18 \mathrm{in.}$

- - [minimus], Baby W. 3 in. pots.

HEDERA helix, English Ivy. 4 in. pots.

- - [baltical], (Baltic I.). Pot grown.

- - [gracilis], (Miniature-Leaved E. I.) 4 in. pots.

HUMULUS lupulus, Common Hop.

HYDRANGEA petiolaris, Climbing $H .3$ in. pots.

LONICERA flava, Yellow Honeysuckle. Pot grown.

- japonica, Japanese H. Pot grown.

- periclymenum belgica, Dutch Woodbine. Pot grown.

\section{- sempervirens, Trumpet $H$. $2-3 \mathrm{ft}$.}

LYCIUM chinense, Chinese Matrimony Vine. 1-2 ft. 
WISTERIA floribunda, (double form).

- - [alba], White Weeping W. Pot grown, 2 yr.

- multijuga, Longcluster W. 2-3 ft.

- sinensis, Chinese W. 3 yr.

- alba, White C. W. 2-3 ft.

- venusta, Silky W. 4 yr. 
$+\frac{1}{2}$

201

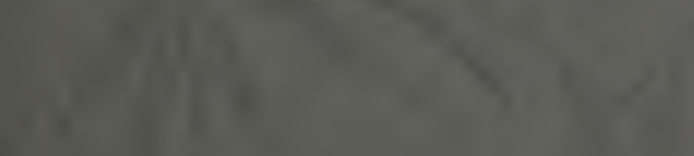

$-7$

,

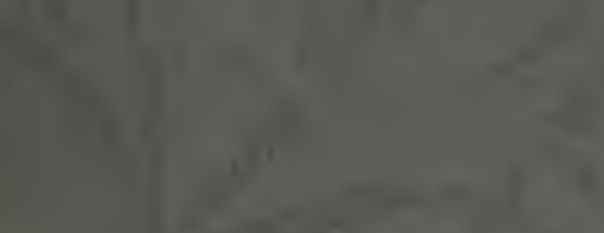

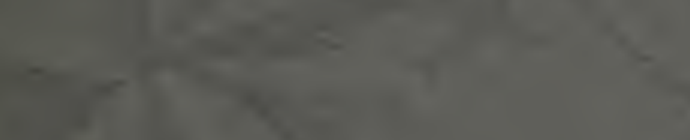
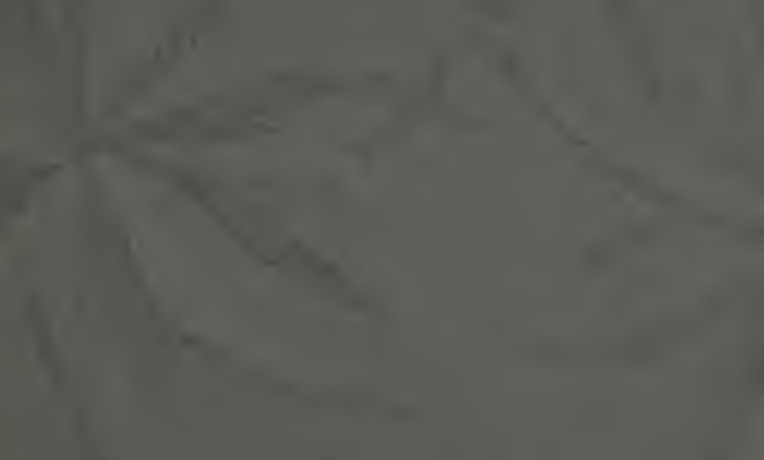

1

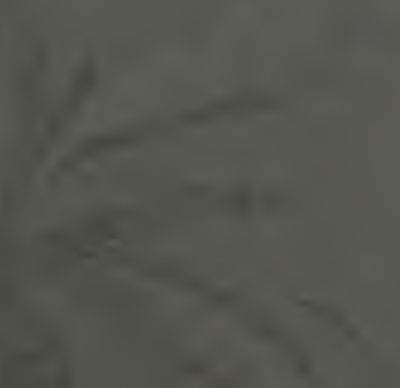

$$
-3
$$



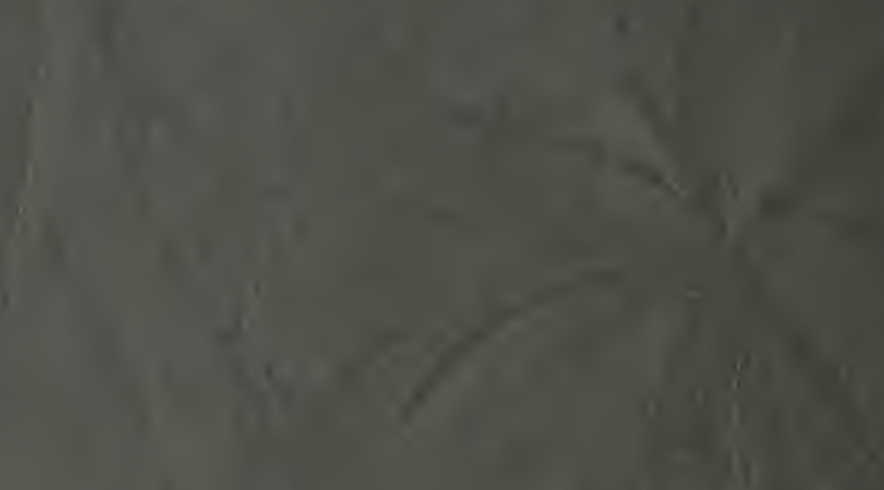

$x^{3}=$

(1)

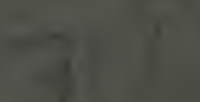

in

in 1
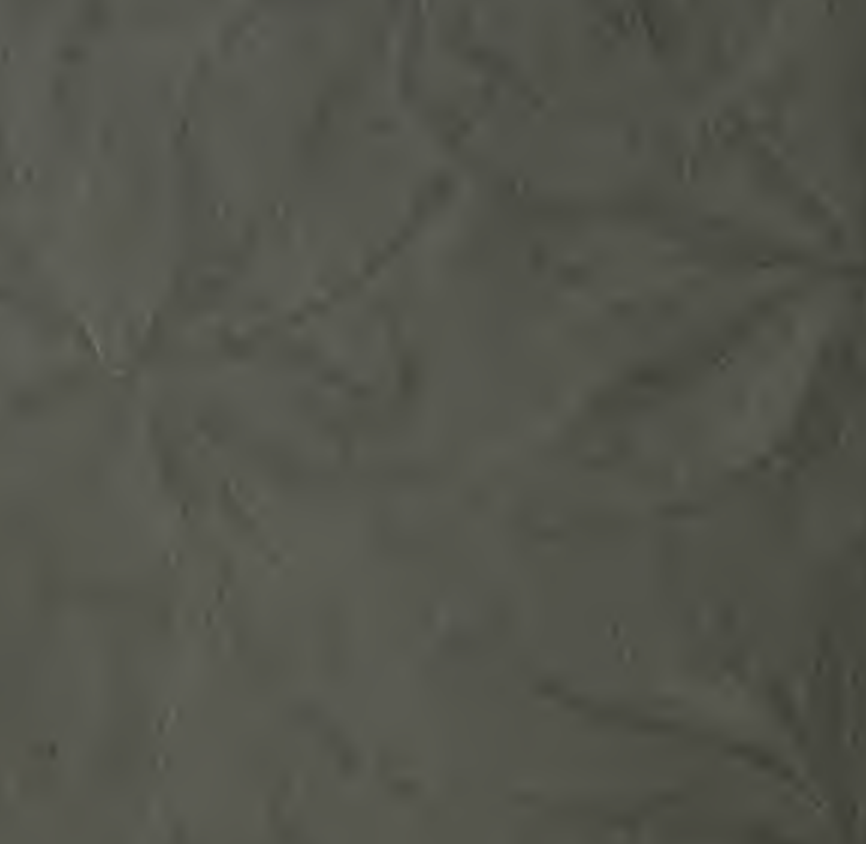

1 